\title{
Olfactory Bulb and Amygdala Gene Expression Changes in Subjects Dying with COVID-19
}

Ignazio S. Piras ${ }^{\mathrm{a}}$, Matthew J. Huentelman ${ }^{\mathrm{a}}$, Jessica E. Walker ${ }^{\mathrm{b}}$, Richard Arce ${ }^{\mathrm{b}}$, Michael J. Glass ${ }^{\mathrm{b}}$, Daisy Vargas ${ }^{\mathrm{b}}$, Lucia I. Sue ${ }^{\mathrm{b}}$, Anthony J. Intorcia ${ }^{\mathrm{b}}$, Courtney M. Nelson ${ }^{\mathrm{b}}$, Katsuko E. Suszczewicz ${ }^{\mathrm{b}}$, Claryssa L. Borja ${ }^{\mathrm{b}}$, Marc Desforges ${ }^{\mathrm{c}}$, Michael Deture ${ }^{d}$, Dennis W. Dickson ${ }^{d}$, Thomas G. Beach ${ }^{b}$ and Geidy E. Serrano ${ }^{b}$

${ }^{a}$ Translational Genomics Research Institute, Neurogenomics Division

${ }^{\mathrm{b}}$ Banner Sun Health Research Institute, Sun City, AZ

${ }^{\circ}$ Centre Hospitalier Universitaire Sainte-Justine, Laboratory of Virology, Montreal, Canada

${ }^{\mathrm{d} M a y o}$ Clinic College of Medicine, Mayo Clinic Florida, Jacksonville, FL

Correspondence: Geidy E. Serrano, Banner Sun Health Research Institute 10515 West Santa Fe Drive, Sun City, AZ 85351

Telephone: 623-832-5328

Fax: 623-815-2960

Geidy.serrano@bannerhealth.com 
medRxiv preprint doi: https://doi.org/10.1101/2021.09.12.21263291; this version posted September 15, 2021. The copyright holder for this preprint (which was not certified by peer review) is the author/funder, who has granted medRxiv a license to display the preprint in perpetuity.

\section{ABSTRACT}

It is made available under a CC-BY-ND 4.0 International license .

In this study we conducted RNA sequencing on two brain regions (olfactory bulb and amygdala) from subjects who died from COVID-19 or who died of other causes. We found several-fold more transcriptional changes in the olfactory bulb than in the amygdala, consistent with our own work and that of others indicating that the olfactory bulb may be the initial and most common brain region infected. To some extent our results converge with pseudotime analysis towards common processes shared between the brain regions, possibly induced by the systemic immune reaction following SARS-CoV-2 infection. Changes in amygdala emphasized upregulation of interferon-related neuroinflammation genes, as well as downregulation of synaptic and other neuronal genes, and may represent the substrate of reported acute and subacute COVID-19 neurological effects. Additionally, and only in olfactory bulb, we observed an increase in angiogenesis and platelet activation genes, possibly associated with microvascular damages induced by neuroinflammation. Through coexpression analysis we identified two key genes $(C A M K 2 B$ for the synaptic neuronal network and $C O L 1 A 2$ for the angiogenesis/platelet network) that might be interesting potential targets to reverse the effects induced by SARS-CoV-2 infection. Finally, in olfactory bulb we detected an upregulation of olfactory and taste genes, possibly as a compensatory response to functional deafferentation caused by viral entry into primary olfactory sensory neurons. In conclusion, we were able to identify transcriptional profiles and key genes involved in neuroinflammation, neuronal reaction and olfaction induced by direct CNS infection and/or the systemic immune response to SARS-CoV-2 infection. 
medRxiv preprint doi: https://doi.org/10.1101/2021.09.12.21263291; this version posted September 15, 2021. The copyright holder for this preprint (which was not certified by peer review) is the author/funder, who has granted medRxiv a license to display the preprint in perpetuity.

\section{INTRODUCTION}

It is made available under a CC-BY-ND 4.0 International license .

The coronavirus SARS-CoV-2 is primarily associated with severe respiratory disease, termed COVID-19 disease, but there have also been numerous clinical reports of an accompanying broad range of neurological signs, symptoms and syndromes, affecting up to $36 \%$ of patients ${ }^{1-10}$, although it is not clear whether these are due to direct viral brain effects or to systemic reactions to critical illness, including coagulopathy, sepsis, autoimmune mechanisms or multiorgan failure ${ }^{11}$.

There is abundant evidence that coronaviruses are able to invade the CNS, and two previous pandemic coronaviruses, SARS-CoV and MERS-CoV, are documented to have caused similar human syndromes as has have been observed with COVID-19 ${ }^{12-38}$. Two human coronaviruses, strains 229E and OC43, were detected by RT-PCR, Northern hybridization and in-situ hybridization in $44 \%$ and $23 \%$, respectively, of 90 human brains obtained from multiple brain banks throughout Europe, the UK and North America ${ }^{32}$, suggesting that, once brain invasion occurs, coronaviruses may persist for long periods of time in the human brain.

There have been more than 20 published studies ${ }^{11,39-58}$ that used RT-PCR methods to interrogate SARSCoV-2 genomic presence in postmortem brain tissue, and although results have differed between studies, the overall conclusion that most of these investigators have reached is that SARS-CoV-2 brain invasion occurs in only a relatively small fraction of those that have died of COVID-19 and that $\mathrm{Ct}$ values and viral copy numbers are generally low, perhaps only representing residual genomic fragments. It is apparent that differing PCR protocols also differ in their sensitivity and specificity ${ }^{58-60}$ and therefore the true prevalence of viral brain entry and proliferation is still uncertain. The detection of subgenomic SARS-CoV-2 sequences has been suggested to prove that in situ viral replication has taken place. However, even in COVID-19 lung tissue, in one study only a subset of cases were found positive for these ${ }^{40}$ and another study found that subgenomic fragments in the throat were only present in the first week of infection ${ }^{61}$. One group has speculated that viral brain infection may be a "transient phenomenon" ${ }^{62}$. It may therefore prove difficult to unequivocally identify the postmortem CNS presence of viable, reproducing SARS-CoV-2.

Of possible CNS entry points, both clinical and autopsy evidence has converged on the olfactory bulb, with its immediate neural connection to the olfactory sensory epithelium in the nasopharynx ${ }^{54,58,63-65}$. Whole or partial loss of the sense of smell is present in $60 \%$ of COVID-19 patients ${ }^{64,66,67}$. The olfactory mucosa strongly expresses angiotensin converting enzyme-2 (ACE2) and neuropilin-1, probable cellular access cofactors for 
medRxiv preprint doi: https://doi.org/10.1101/2021.09.12.21263291; this version posted September 15, 2021. The copyright holder for this preprint (which was not certified by peer review) is the author/funder, who has granted medRxiv a license to display the preprint in perpetuity. It is made available under a CC-BY-ND 4.0 International license .

SARS-CoV-2 ${ }^{15,20,68-71}$. While there have been almost two dozen reports using PCR to localize SARS-CoV-2

RNA in postmortem COVID-19 brain tissue, only a few of these have assayed more than a very few brain regions. One study that assayed multiple brain regions found positive olfactory bulb amplification in $8 / 15$ (53\%) while all other brain regions except midbrain were negative ${ }^{58}$. This result parallels that of our own ${ }^{72}$ study (with follow up results in preparation) in which olfactory bulb was PCR-positive in 8/20 cases (40\%) while of a total of 16 brain regions assayed, the next most-commonly-positive area was amygdala, with only 2 positive cases (10\%). However, aside from olfactory bulb, the prevalence and copy numbers of PCR-detected SCV2 viral genome in autopsied COVID-19 brains seems insufficient to account for the much more prevalent neurological signs and symptoms.

Also puzzling is the relative lack of microscopic brain pathology in the great majority of autopsied COVID19 cases. Although cases of meningitis and/or encephalitis have occurred ${ }^{46,51,52,73-78}$, elements of the classical neuropathology of viral CNS infections ${ }^{79,80}$, including lymphocytic leptomeningitis and encephalitis, microglial nodules, perivascular lymphocytic cuffing, focal demyelination and viral inclusions, have most often been absent. The lesions that have more been frequently reported, such as those with acute and subacute ischemic and/or hemorrhagic features ${ }^{45,51,53,54,56,73,78,81-88}$, are common in unselected autopsy series. As almost all studies have not included appropriate non-COVID-19 control cases, it is difficult to know what lesions are specifically due to, or are more common in, COVID-19 brains. We found that acute and subacute ischemia or infarction was present in the brains of $14 \%$ of 691 consecutive pre-COVID-19 autopsies with or without concurrent autopsy-proven pneumonia, while the rate of acute brain hemorrhage was $1.4 \%$ and $2.0 \%$ for those with or without acute pneumonia, respectively ${ }^{89}$. In comparison, in reviews of COVID-19 publications, reported clinically-determined rates of acute brain infarction range from $0.5 \%$ to $20 \%$ while rates of acute brain hemorrhage range from $0.13 \%$ to $2 \%$ 4,5,11,44,45,47,50,52-54,56,57,73,78,82,84-88,90-103.

With direct viral brain damage seemingly uncommon in COVID-19, it appears to be more likely that its neurological manifestations are mostly due to systemic reactions that are common to critical illnesses, and may therefore be lacking specific histopathological correlates, but may be reflected by functional changes. Gene expression is a functional change that is sensitive to both local and systemic influences and may occur without accompanying alterations in cellular structure. Cell infection by SARS-CoV-2 may represent a direct stress, which will induce changes in cellular transcriptome. HCoV-OC43 infection of neuronal cells has been shown to 
medRxiv preprint doi: https://doi.org/10.1101/2021.09.12.21263291; this version posted September 15, 2021. The copyright holder for this

preprint (which was not certified by peer review) is the author/funder, who has granted medRxiv a license to display the preprint in perpetuity.

It is made available under a CC-BY-ND 4.0 International license.

induce the unfolded protein response. Changes in CNS gene expression could account for much of the

neurological spectrum of COVID-19. We therefore used RNA sequencing technology to assess regional brain gene expression in postmortem brains of subjects that died with COVID-19, focusing on the olfactory bulb and the closely-connected amygdala.

\section{MATERIALS AND METHODS}

\section{Human Subjects and Characterization}

The human subjects were derived from Banner Sun Health Research Institute (BSHRI) in Sun City, Arizona $(n=10)$, and from the Mayo Clinic in Jacksonville, Florida $(n=10)$. Clinical, neuropathological and RT-PCR results, including brain regional results, are described in our prior publication ${ }^{72}$ and are briefly re-summarized in Table 1. All COVID-19 subjects had positive clinical diagnostic test results for SARS-CoV-2 and all were considered to have died in 2020 as a result of severe COVID-19. Since our prior publication ${ }^{72}$, we have performed additional SARS-CoV-2 PCR assays, using alternate protocols (manuscript in preparation), on frozen samples of amygdala and olfactory bulb and these detected SARS-CoV-2 RNA in olfactory bulb from 6 additional cases, giving a new total of $8 / 20$ SARS-CoV-2-positive cases in olfactory bulb. For amygdala these new protocols detected one additional case, giving a new total of 2 SARS-CoV-2-positive cases in amygdala.

Olfactory bulb and amygdala brain tissue from additional human subjects $(n=20)$ without COVID-19 (who died prior to the COVID-19 pandemic) were used as a gene expression control group. Their basic characteristics are also listed in Table 1. The mean ages of the COVID-19 and non-Covid-19 control groups are 77.5 (SD 12.9) and 83.9 (SD 8.9) respectively (ns); each group has 9 females and 11 males. The control group includes equal numbers of subjects with and without autopsy-proven non-COVID-19 pneumonia. The COVID-19 group differs from the non-COVID-19 control group in the fraction with neuropathologicallydiagnosed neurodegenerative conditions ( $6 / 20$ vs $10 / 20$, respectively) but this was not significant on a Fisher Exact test $(p=0.33)$.

\section{Gene Expression}

RNA was extracted from $20 \mathrm{mg}$ of frozen tissue using Qiagen RNeasy Plus mini kits (Qiagen, cat \#74134) following the manufacturer's instructions. The RNA Integrity Number (RIN) was assessed using Agilent's RNA 
medRxiv preprint doi: https://doi.org/10.1101/2021.09.12.21263291; this version posted September 15,2021 . The copyright holder for this preprint (which was not certified by peer review) is the author/funder, who has granted medRxiv a license to display the preprint in perpetuity. It is made available under a CC-BY-ND 4.0 International license .

6000 Nano Kit (Agilent, cat \# 5067-1511) on the Bioanalyzer 2100. The mean RIN was greater than 8.0.

Sequencing libraries were prepared with $100 \mathrm{ng}$ of total RNA using Illumina's Stranded Total RNA Prep Ligation with Ribo-Zero Plus (Illumina, Inc. cat \# 20040529) following the manufacturer's protocol. The final library was sequenced by 2 x 100bp paired-end sequencing on an Illumina NovaSeq6000.

After sequencing, FASTQs files were aligned to the Human Reference Genome HG38 using STAR ${ }^{105}$, and summarized at the gene level with HTSeq. Quality controls were conducted using MultiQC software ${ }^{106}$ and Principal Component Analysis (PCA). Samples with $\mathrm{RIN}<4$, total number of reads $<20 \mathrm{M}$, and uniquely mapped reads $<70 \%$ were excluded from the downstream analysis. Genes with a total count of less than 10 were excluded. Normalization was performed using DEseq2. Differential gene expression was calculated between the COVID-19 samples and the controls using DEseq2, adjusting for age at death, sex, brain tissue source (Banner or Mayo Clinic) and neuropathologically-determined presence or absence of a diagnostic level of a major neurodegenerative disease. The presence or absence of non-COVID-19 pneumonia in control cases was also considered but preliminary analyses (not shown) indicated this was not a significance influence. Comparison of olfactory bulb gene expression in COVID-19 cases with or without PCR-detected SARS-CoV-2 showed very few differences in gene expression so subsequent comparisons involving olfactory bulb did not subdivide the COVID-19 cases on this basis (preliminary data, not shown). Genes with a False Discovery Rate (FDR) smaller than 0.05 were considered differentially expressed genes (DEGs). Pathway analysis was conducted on the DEGs using a hypergeometric statistic referencing the REACTOME database as implemented in the clusterProfiler $\mathrm{R}$ package.

Lists of cell specific genes were generated from a brain single-nucleus RNA sequencing dataset from the DLPFC ${ }^{107}$ that included Alzheimer's Disease cases (AD) and non-demented controls (ND) (total: $\left.n=48\right)$. Data were downloaded from the Accelerated Medicine Partnership-AD portal (AMP-AD; accession number syn18485175). The filtered dataset consisted of a total of 70,634 droplet-based single-nuclei and 17,352 genes from: astrocytes (Ast), endothelial cells (End), excitatory neurons (Ex), inhibitory neurons (In), microglia (Mic), oligodendrocytes (Oli), oligodendrocyte precursor cells (Opc), and pericytes (Per). After excluding the AD samples, the data matrix was imported into Seurat ${ }^{108}$ and normalized using the function "NormalizeData" with the option "LogNormalize", using a scale factor of 10,000. Then, each gene was assigned to a cell class modeling a linear regression where the expression levels were the dependent variable and the cell type the 
medRxiv preprint doi: https://doi.org/10.1101/2021.09.12.21263291; this version posted September 15, 2021. The copyright holder for this preprint (which was not certified by peer review) is the author/funder, who has granted medRxiv a license to display the preprint in perpetuity.

It is made available under a CC-BY-ND 4.0 International license .

predictors, adjusting for sex, age, and postmortem interval. A transcript was assigned to a cell type when: 1) the adjusted $p$-values (FDR) was $p<0.05$, and 2 ) the regression coefficient of the enriched cell type had a ratio $>1.81$ with the second enriched cell type. The cutoff was established after testing all of coefficient ratios from 1 to 5 until the variation of the number of unclassified genes stabilized to under $0.5 \%$. We obtained a list of 5,641 cell-specific genes, which were used as gene sets to run enrichment analysis on the differentially expressed genes. The analysis was conducted using the $\mathrm{R}$ function enrichment ( $\mathrm{R}$ package bc3net) adjusting the results for multiple testing with the FDR method.

We conducted WGCNA analysis to detect relevant coexpression networks associated with the disease ${ }^{109}$. The count table was normalized with the voom method ${ }^{110}$, and adjusted for the confounding factors as in the differential expression analysis using the function removeBatchEffect as implemented in limma ${ }^{111}$. Genes with less than 5 total cpm counts were removed from the dataset. Finally, we retained the $50 \%$ of the most variable genes after computing the Median Absolute Deviation (MAD) with the goal of excluding genes with low variability that contribute noise in the coexpression networks. We computed soft-thresholding power ( $\beta)$, using the pickSoftThreshold function. Then, we plotted the values against the scale-free fit index and selected the lowest power for which the scale-free topology fit index curve flattens out upon reaching a $r^{2}=0.900{ }^{112}$. We generated a signed coexpression network and identified the resulting clusters using the function blockwiseModules with the following parameters: TOMtype: "signed", minimum module size = 30, mergeCutHeight $=0.30$, deepSplit $=2$; reassign threshold $=1.0^{-06}$, and pamRespectsDendro $=$ "TRUE". We computed the eigengene values for each individual and module by singular value decomposition (SVD) ${ }^{113}$. The eigengenes were compared by module between COVID-19 positive and controls using a linear model as implemented in limma, adjusting the p-values for multiple testing by accounting for the number of modules using the FDR method. Covariates were not included in the model since we used the adjusted expression matrix. We conducted Gene Ontology (GO) enrichment analysis on the differentially expressed modules associated with COVID-19 status by the means of the R-package enRichment, using as background the intersection of given genes and genes present in GO. P-values of the GO enrichment analysis were adjusted using the Bonferroni method. The enrichment for genes specifically expressed in certain cell types was conducted using the above-described cell specific markers by means of a hypergeometric test as implemented 
medRxiv preprint doi: https://doi.org/10.1101/2021.09.12.21263291; this version posted September 15, 2021. The copyright holder for this preprint (which was not certified by peer review) is the author/funder, who has granted medRxiv a license to display the preprint in perpetuity.

It is made available under a CC-BY-ND 4.0 International license .

in the $\mathrm{R}$ function enrichment. Finally, the top hub genes in the coexpression modules were identified using the function chooseTopHubInEachModule as implemented in the WGCNA package.

\section{Pseudotime analysis}

Pseudotime analytical approaches are machine learning based algorithms capable of extracting latent temporal information from cross-sectional studies ${ }^{114}$. First, the dataset was normalized and filtered as described for the WGCNA analysis. Then, pseudotime trajectories were generated using the phenoPath method modeling the brain region as a prior factor of interest ${ }^{114}$. Finally, we correlated the gene expression to the pseudotime trajectories using the biweight midcorrelation to detect genes associated with the estimated disease progression ${ }^{109}$ adjusting the results with the FDR method. Pathway analysis was conducted using the genes significantly correlated with pseudotime by means of the clusterProfiler $\mathrm{R}$ package.

\section{RESULTS}

\section{Differential expression}

After removing low quality samples, the final sample size was 38 for amygdala (AMY) (COVID-19+ = 18; $C T L=20)$ and 40 for olfactory bulb $(O B T)(C O V I D-19+=20 ; C T L=20)$. The remaining samples had a total of 5,003.6 million (M) of reads (range: $20.1 \mathrm{M}-234.6 \mathrm{M}$ ), with an average percentage of uniquely mapped reads of $82.8 \%$ (range: $72.8 \%$ - 90.3\%). After differential expression analysis we obtained 1,283 DEGs in AMY (576 upregulated and 707 downregulated) (Fig. 1A). In the OBT samples we obtained 5,405 DEGs (2,546 upregulated and 2,859) dowregulated) (Fig 1B). IFI6, INSRR and ITGA6 were the most significant genes in AMY, whereas UBQLN2, CLCNA and MAPK1 were the most significant genes in OBT. The top 9 genes for the two regions are reported in Figure $\mathbf{2 A}$ and $\mathbf{2 B}$, whereas the complete list of DEGs is reported in Table $\mathbf{S 1}$ and S2. Pathway analysis revealed differential processes associated with AMY and OBT. In AMY we observed an enrichment of immune pathways (including interferon signaling and the toll like receptor cascade), mostly due to upregulated genes. Across downregulated genes we observed an enrichment of synaptic and neuronal pathways (Figure 3; Table S3). In OBT we observed an enrichment of RNA metabolism and synaptic 
medRxiv preprint doi: https://doi.org/10.1101/2021.09.12.21263291; this version posted September 15, 2021. The copyright holder for this

preprint (which was not certified by peer review) is the author/funder, who has granted medRxiv a license to display the preprint in perpetuity.

It is made available under a CC-BY-ND 4.0 International license.

pathways. However, the top pathway enriched in upregulated genes was Olfactory signaling and collagen pathways. Finally, synaptic pathways were enriched within downregulated genes (Figure 3; Table S4).

Cell specific gene enrichment across DEGs revealed astrocyte (Ast) and endothelial (End) specific genes were significantly over-represented in AMY. We also analyzed the enrichment results for upregulated and downregulated DEGs separately, detecting Ast, End, Per, Mic and Opc overrepresented in upregulated genes in AMY. Additionally, Ex and In were significantly enriched in the downregulated gene set in AMY. In OBT, when considering all the DEGs we did not detect any significant cell-specific enrichment. However, we detected a significant enrichment of End, Per, and Mic across upregulated genes, and enrichment of both Ex and In in the downregulated genes (Figure 4).

\section{WGCNA analysis}

We obtained a total of six coexpression modules (Figure S1) in amygdala with the number of genes in each module ranging from 204 (red module) to 3,049 (turquoise). After eigengene extraction and differential analysis, no modules were differentially expressed between COVID-19+ and CTL in AMY (Figure S1). In OBT we obtained 15 modules with the number of genes in each module ranging from 39 (midnightblue) to 1,904 (turquoise). Interestingly, 11 modules were differentially expressed between COVID-19+ and CTL, with the top modules being black (downregulated in COVID-19+) and red (upregulated) (both: FDR $=1.68^{-11}$ ) $($ Figure 5). Relationships between these modules are reported in Figure S2. We conducted Gene Ontology (GO) and cell enrichment analysis on these eleven modules and found GO enriched classes in eight of the modules. The top two modules (black and red) were enriched for ribosome/RNA metabolism and cilium/taste, respectively. Other modules were enriched for development/angiogenesis (green, upregulated, and enriched for End and Per), immune system (tan, upregulated), and synaptic signaling (green-yellow and turquoise, both downregulated and enriched for neuronal cell genes) (Table S5). Interestingly, the two synaptic modules were not related to each other (Figure S2) despite a similar functional enrichment. The summary of the WGCNA analysis, including modules, GO and cell enrichment, and a list of the hub genes is reported in Table 2.

\section{Pseudotime analysis}

The pseudotime trajectory was generated modeling the brain region as the prior factor of interest. As shown in the PCA analysis in Figure 6A, the trajectories for AMY and OBT converge from distinct starting 
medRxiv preprint doi: https://doi.org/10.1101/2021.09.12.21263291; this version posted September $15,2021$. The copyright holder for this preprint (which was not certified by peer review) is the author/funder, who has granted medRxiv a license to display the preprint in perpetuity.

It is made available under a CC-BY-ND 4.0 International license .

points possibly due to brain region heterogeneity. However, these results suggest that the pathology might drive similar changes across the two brain regions, resulting in converging trajectories. Interestingly, we detected a significant difference of pseudotime between cases and controls, with an increase in COVID-19+ cases (t-test: $p=0.0006$ in AMY, and $p=0.011$ in OBT) (Figure 6B). We detected a total of 5,731 (amygdala) and 4,394 (olfactory bulb) genes significantly correlated with pseudotime trajectories (FDR < 0.05). We conducted pathways analysis and detected similar pathways between the two regions. Across positively correlated genes we observed immune system and extracellular matrix pathways in both amygdala and olfactory bulb. Finally, negatively correlated genes were enriched for neuronal and synaptic pathways. The only differential pathways we detected were related to platelet activation processes/hemostasis, which was only detected in the olfactory bulb (Figure 7; Table S6 and S7).

We extracted the genes significantly associated with pseudotime but not differentially expressed between COVID-19+ and controls with the goal of highlighting genes and processes not detectable in the differential expression analysis. We detected a total of 4,275 genes only associated with pseudotime in amygdala and 3,102 only associated with pseudotime in olfactory bulb (Table S8 and Table S9, respectively). The top genes for AMY and OBT are reported in Figure S3. The top three genes for amygdala were SCN3B, BASP1 and $A D D 2$ (negatively correlated), and the top three genes for the olfactory bulb were MAP7D2, ADARB1 and LMTK2.

\section{DISCUSSION}

In this study we conducted RNA sequencing in postmortem brain tissue from COVID-19 patients and controls, characterizing the amygdala (AMY) and olfactory bulb (OBT). Overall, we detected a higher dysregulation in OBT than AMY, demonstrated by the number of DEGs detected in the two regions $(5,405$ in OBT vs 1,283 in AMY), and by the results from the WGCNA analysis. Specifically, the coexpression networks detected in AMY were not significantly different between patients and controls, whereas we detected 11 modules with significant changes in OBT. At the pathway level, we detected similar biological processes enriched in both regions, these included the downregulation of synaptic genes and immune system activation, but also specific processes (olfactory/taste pathways and angiogenesis/platelet aggregation in OBT).

Pseudotime analysis uncovered converging trajectories highlighting some common processes involved in 
medRxiv preprint doi: https://doi.org/10.1101/2021.09.12.21263291; this version posted September 15,2021 . The copyright holder for this preprint (which was not certified by peer review) is the author/funder, who has granted medRxiv a license to display the preprint in perpetuity.

It is made available under a CC-BY-ND 4.0 International license .

disease progression which included the immune system response and the downregulation of synaptic/neuronal genes. Finally, we were able to detect genes associated with disease progression not observed in the differential expression analysis.

With a much larger number of DEGs in OBT than in AMY, with several co-expression network changes between patients and controls in OBT, but no significant differences in AMY, the developing picture of OBT as central to CNS COVID-19 is supported by our results. OBT is considered one of the likely entry-points of SARS-CoV-2 in the human brain ${ }^{54,58,63-65}$, and this fact might explain the larger number of transcriptional changes observed. Ageusia and anosmia are typical symptoms of COVID-19 ${ }^{64,66,67,115,116}$, being a probable consequence of the early viral colonization of the primary olfactory neuroepithelium. We detected a significant enrichment and upregulation of olfactory/taste receptor genes in OBT among the upregulated DEGs and in the red WGCNA module ( $n=587$ genes), respectively. The hub gene in the coexpression network enriched for taste receptors and signaling was DMTF1 (Cyclin D Binding Myb Like Transcription Factor 1), encoding for a transcription factor induced by the oncogenic Ras signaling pathways and functioning as a tumor suppressor. These pronounced gene expression changes in OBT might be due to direct OBT neuroinvasion or indirect effects of systemic inflammation, but it also seems possible that this may represent a reaction to structural or functional deafferentation resulting from direct SARS-CoV-2 infection and inflammation of primary olfactory neuroepithelium ${ }^{117,118}$.

Some of our analyses converge towards an increase of immune system activity in both regions. Immune pathways are upregulated in AMY, and, by WGCNA analysis, we found an upregulated module in the OBT enriched for the same processes. The same results were detected during the pseudotime analysis.

Additionally, across upregulated genes we detected a significant enrichment of microglia genes in both regions and astrocyte genes in AMY. The hub gene detected in the immune module was PARP9 (Poly(ADP-Ribose) Polymerase Family Member 9) which is involved in interferon-mediated antiviral defense ${ }^{119,120}$. It has been recently demonstrated that the ectopically expressed SARS-CoV-2 Nsp3 macrodomain hydrolyzes PARP9/DTX3L-dependent ADP-ribosylation induced by IFN signaling suggesting a role for this modification as a putative effector of the IFN response ${ }^{121}$. However, previous reports demonstrated an induction of interferon signaling genes and IFNy-induced STAT1 phosphorylation ${ }^{119,120}$. Neuroinflammation has been widely reported in COVID-19 disease ${ }^{122-124}$ but relatively few reports characterize this in detail and broad confirmation is 
medRxiv preprint doi: https://doi.org/10.1101/2021.09.12.21263291; this version posted September 15,2021 . The copyright holder for this preprint (which was not certified by peer review) is the author/funder, who has granted medRxiv a license to display the preprint in perpetuity. It is made available under a CC-BY-ND 4.0 International license .

lacking. Additionally, there are considerable interindividual differences in the circulating immune profile, as well as changes during the clinical course and in relation to the ultimate outcome, with some evidence of an early immunosuppression or maladapted immune response ${ }^{125-127}$. Early lymphopenia, including decreases in circulating CD4+ and CD8+ cells, are relatively common ${ }^{127}$. Generally, however, the immune response triggered by COVID-19 infection results in an increase of serum proinflammatory cytokines as IL-1, IL-6, IL-10 and TNF-a ${ }^{128,129}$. TNF- $\alpha$ can cross the blood-brain-barrier (BBB) or reach the brain via circumventricular organs (CVOs) ${ }^{130}$ and activate microglia and astrocytes ${ }^{131}$. This triggers an increase in phagocytosis but also secretion of inflammatory molecules by the microglia including glutamate and quinolinic acid ${ }^{132}$, resulting in glutamate release and upregulation of NMDA receptors, possibly inducing altered learning, memory and neuroplasticity ${ }^{131}$. All this evidence supports how neuroinflammation may contribute to the cognitive symptoms reported in COVID-19 disease ${ }^{129}$.

We detected a deregulation of synaptic and neuronal genes in both OBT and AMY associated with COVID19 progression, as demonstrated by pathways, WGCNA and pseudotime analysis. Some of the relevant genes were the hubs of the two distinct WGCNA coexpression networks deregulated in OBT, enriched for synaptic and neuronal processes as well as for both excitatory and inhibitory neuronal genes. CNR1 (cannabinoid receptor $1-\mathrm{CB} 1)$ is the hub of the greenyellow module, and mediates the biological activity of both endogenous and exogenous cannabinoids centered on psychoactive functions ${ }^{133}$. There are multiple lines of evidence regarding the effects of cannabinoid receptors on viral infection. Activation of CB1 inhibits the production of pro-inflammatory mediators, such as NO or TNF $\alpha$, and inhibit Ca2+ channels. On one side, the activation of CB1 increases the progression of viral diseases through an immunosuppressive effect, but on the other side it might inhibit the immune effects derived from the viral infection by eliciting and immunoprotective profile $^{133}$. In our study we see a deregulation of the network regulated by CB1, and we hypothesize this might be a feedback effect aimed at reducing the neuroinflammatory state induced by the viral infection. The hub gene of the turquoise module ( $\mathrm{n}=1,904$ genes) is CAMK2B (Calcium/Calmodulin Dependent Protein Kinase II Beta), and is involved in dendritic spine and synapse formation, neuronal plasticity and development ${ }^{134}$, specifically during cytoskeleton reorganization. Additionally, $C A M K 2 B$ mutations and mRNA alterations were associated with neurodevelopmental diseases, epilepsy and intellectual disability and other neuropsychiatric diseases such as schizophrenia ${ }^{135-137}$. Cognitive and attention deficits, new-onset anxiety, depression, 
medRxiv preprint doi: https://doi.org/10.1101/2021.09.12.21263291; this version posted September $15,2021$. The copyright holder for this preprint (which was not certified by peer review) is the author/funder, who has granted medRxiv a license to display the preprint in perpetuity.

It is made available under a CC-BY-ND 4.0 International license .

psychosis and seizures have been observed in some patients with COVID-19, unrelated to respiratory

insufficiencies, suggesting brain related alterations that are independent of oxygen saturation ${ }^{138}$. These

symptoms, but also excitotoxicity and synaptic/neuronal loss may be the consequence of the cytokine storm

induced by COVID-19 infection ${ }^{130-132}$. We hypothesize that deregulation of the synaptic genes observed in the CAMK2B network might be the consequence of immune system activation effects caused by COVID-19 infection and that these changes may be the critical ones responsible for the short and long-term neurological effects. CAMK2B might be an interesting candidate target to reverse and minimize these short and long term COVID-19 neurological effects. In summary, the results for the WGNCA "synaptic" modules highlight two differential biological processes: a feedback effect of the cannabinoid system to limit the damages of neuroinflammation and synaptic disfunctions driven by the neuroinflammation induced by the infection. It is important to stress that the two modules are not related (see Table S2) representing two distinct biological processes.

One of the OBT-specific processes we identified was angiogenesis/blood vessel development (WGCNA green module) and platelet activation/hemostasis (pseudotime analysis) with upregulation of these processes in COVID-19+ patients. Additionally, we detected enrichment of endothelial cell and pericyte specific genes in OBT. The hub gene in the green module was COL1A2 (Collagen Type I Alpha 2 Chain), encoding for the $\alpha 2$ polypeptide of the Type I collagen, the most abundant collagen type in the human body and also a powerful angiogenesis inducer ${ }^{139}$. SARs-CoV-2 has been hypothesized to enter brain endothelial cells activating neutrophils, macrophages, and thrombin production, promoting microthrombi deposition, capillary congestion and ischemic lesions causing tissue hypoxia and disturbing neurotransmitter synthesis ${ }^{49,140}$. Angiogenesis is a response against these damages and local hypoxia, and in COVID-19 has been observed in different tissues, including the brain ${ }^{141}$. COL1A2 might potentially be a candidate target to reverse/minimize the microvascular damages induced by COVID-19 neuroinflammation.

\section{CONCLUSIONS}

We were able to identify molecular processes and genes associated with the effects of COVID-19 on the brain. Our results indicate the involvement of neuroinflammation as a major driver of COVID-19 effects in the brain, finding an upregulation in OBT and AMY, mostly associated with IFN pathways activation. The effect of $P A R P 9$ as a key driver of neuroinflammation should be further investigated, since there are contrasting results from 
medRxiv preprint doi: https://doi.org/10.1101/2021.09.12.21263291; this version posted September 15, 2021. The copyright holder for this

preprint (which was not certified by peer review) is the author/funder, who has granted medRxiv a license to display the preprint in perpetuity.

It is made available under a CC-BY-ND 4.0 International license .

studies investigating the role as an effector of the IFN cascade. Common observed consequences of the neuroinflammation in COVID-19 are both neurological effects and microvascular damages. Accordingly, we identified a coexpression network downregulated in OBT in COVID-19 patients, and more generally a downregulation of synaptic and neuronal genes in both regions. We hypothesize this deregulation might be associated with the short- and long-term neurological effects of the disease. In this context, CAMK2B might be a key gene and a candidate target to reverse or slow these neurological effects. Finally, we found enrichment for angiogenesis and platelet activation genes, where the angiogenesis gene COL1A2 might be a potential candidate target to antagonize the vascular COVID-19 consequences. All of these results stand in need of further investigation both in vivo and in vitro to assess their potential role in SARS-CoV-2 infection, response, and COVID-19 development and short-/long-term sequelae.

\section{ACKNOWLEDGEMENTS}

This project was supported by a COVID-19 Supplement to a National Institute on Aging grant, (3P30AG019610-20S1), submitted in response to a Notice of Special Interest (NOSI) issued by the National Institute on Aging (NOT-AG-20-022). Biospecimens from the Banner Sun Health Research Institute Brain and Body Donation Program, including those presented in this report, are available to qualified researchers upon request from https://www.brainandbodydonationregistration.org/.

Some of the results published here are in part based on data obtained from the AD Knowledge Portal (https://adknowledgeportal.org). Study data were provided by the Rush Alzheimer's Disease Center, Rush University Medical Center, Chicago. Data collection was supported through funding by NIA grants P30AG10161 (ROS), R01AG15819 (ROSMAP; genomics and RNAseq), R01AG17917 (MAP), R01AG30146, R01AG36042 (5hC methylation, ATACseq), RC2AG036547 (H3K9Ac), R01AG36836 (RNAseq), R01AG48015 (monocyte RNAseq) RF1AG57473 (single nucleus RNAseq), U01AG32984 (genomic and whole exome sequencing), U01AG46152 (ROSMAP AMP-AD, targeted proteomics), U01AG46161(TMT proteomics), U01AG61356 (whole genome sequencing, targeted proteomics, ROSMAP AMP-AD), the Illinois Department of Public Health (ROSMAP), and the Translational Genomics Research Institute (genomic). 
Table 1. Presence of dementia, parkinsonism and neuropathological diagnoses in study subjects, with SCV2 PCR results in olfactory bulb and amygdala for the 20 COVID-19 subjects. B1-10 = BSHRI-derived COVID-19 cases; M1-10 = Mayo Clinic-derived COVID-19 cases; M9 was deleted as this subject was later found not to have had COVID-19; C1-20 = BSHRI-derived non-COVID19 control cases. SCV2 = PCR-positive for SARSCoV-2. Abbreviations for major neuropathologically-diagnosed conditions: $A D=$ Alzheimer's disease dementia; FTLD-TDP = frontotemporal lobar degeneration with TDP-43 proteinopathy; HS = hippocampal sclerosis; MSA = multiple system atrophy; None = age-consistent changes only; PD = Parkinson's disease; $\mathrm{PSP}=$ progressive supranuclear palsy; $\mathrm{VaD}=$ vascular dementia. Pneumonia in control cases refers to autopsy-confirmed non-COVID-19 pneumonia (pre-COVID-19 era); Control cases in this table were not assayed for SCV2; non-COVID-19 control cases were all negative for SCV2 in our prior publication ${ }^{72}$.

\begin{tabular}{|c|c|c|c|c|c|c|}
\hline Case & Age & Sex & $\begin{array}{l}\text { Olf. Bulb } \\
\text { SCV2 }\end{array}$ & $\begin{array}{l}\text { Amygdala } \\
\text { SCV2 }\end{array}$ & Clinical Diagnoses & $\begin{array}{c}\text { Neuropathological } \\
\text { Diagnoses }\end{array}$ \\
\hline B1 & 90s & $\mathrm{M}$ & - & - & $\begin{array}{l}\text { COVID-19; } \\
\text { Dementia }\end{array}$ & AD; VaD; HS; PSP \\
\hline B2 & $70 \mathrm{~s}$ & $F$ & - & - & $\begin{array}{l}\text { COVID-19; } \\
\text { Dementia }\end{array}$ & PD; AD \\
\hline B3 & $70 \mathrm{~s}$ & $\mathrm{M}$ & - & - & $\begin{array}{l}\text { COVID-19; } \\
\text { No dementia or } \\
\text { parkinsonism }\end{array}$ & None \\
\hline B4 & $80 \mathrm{~s}$ & $\mathrm{M}$ & + & + & $\begin{array}{l}\text { COVID-19; } \\
\text { No dementia or } \\
\text { parkinsonism }\end{array}$ & None \\
\hline B5 & $90 \mathrm{~s}$ & $\mathrm{M}$ & + & - & $\begin{array}{c}\text { COVID-19; } \\
\text { Dementia, parkinsonism }\end{array}$ & $A D$ \\
\hline B6 & $70 \mathrm{~s}$ & $M$ & - & - & $\begin{array}{c}\text { COVID-19; } \\
\text { Dementia, parkinsonism }\end{array}$ & AD; PSP \\
\hline B7 & $70 \mathrm{~s}$ & $\bar{F}$ & + & - & $\begin{array}{l}\text { COVID-19; } \\
\text { No dementia or } \\
\text { parkinsonism }\end{array}$ & None \\
\hline B8 & $80 \mathrm{~s}$ & $\mathrm{M}$ & - & - & $\begin{array}{l}\text { COVID-19; } \\
\text { Dementia }\end{array}$ & AD; MSA \\
\hline B9 & $70 \mathrm{~s}$ & $\mathrm{M}$ & + & - & $\begin{array}{l}\text { COVID-19; } \\
\text { No dementia or } \\
\text { parkinsonism }\end{array}$ & None \\
\hline B10 & $60 s$ & $F$ & - & + & $\begin{array}{l}\text { COVID-19; } \\
\text { No dementia or } \\
\text { parkinsonism }\end{array}$ & None \\
\hline M1 & $70 \mathrm{~s}$ & $F$ & - & - & $\begin{array}{l}\text { COVID-19; } \\
\text { Dementia }\end{array}$ & $A D ; V a D$ \\
\hline M2 & $80 \mathrm{~s}$ & $F$ & - & - & $\begin{array}{l}\text { COVID-19; } \\
\text { Dementia }\end{array}$ & $A D$ \\
\hline M3 & $70 \mathrm{~s}$ & $\mathrm{~F}$ & - & - & $\begin{array}{l}\text { COVID-19; } \\
\text { Dementia }\end{array}$ & DLB; AD \\
\hline M4 & $80 \mathrm{~s}$ & $M$ & + & - & $\begin{array}{c}\text { COVID-19; } \\
\text { Parkinsonism }\end{array}$ & PSP \\
\hline M5 & $70 \mathrm{~s}$ & $F$ & - & - & $\begin{array}{c}\text { Dementia, } \\
\text { parkinsonism }\end{array}$ & PSP \\
\hline M6 & $60 s$ & $M$ & - & - & $\begin{array}{l}\text { COVID-19; } \\
\text { Dementia }\end{array}$ & $A D$ \\
\hline M7 & $70 \mathrm{~s}$ & $F$ & - & - & $\begin{array}{c}\text { COVID-19; } \\
\text { Dementia }\end{array}$ & FTLD-TDP; VaD \\
\hline M8 & $70 \mathrm{~s}$ & $M$ & + & - & $\begin{array}{c}\text { COVID-19; } \\
\text { Dementia, parkinsonism }\end{array}$ & VaD; AD \\
\hline
\end{tabular}


medRxiv preprint doi: https://doi.org/10.1101/2021.09.12.21263291; this version posted September 15, 2021. The copyright holder for this preprint (which was not certified by peer review) is the author/funder, who has granted medRxiv a license to display the preprint in perpetuity.

It is made available under a CC-BY-ND 4.0 International license .

\begin{tabular}{|c|c|c|c|c|c|c|}
\hline M10 & $30 \mathrm{~s}$ & $M$ & + & - & $\begin{array}{l}\text { COVID-19; } \\
\text { No dementia or } \\
\text { parkinsonism }\end{array}$ & None \\
\hline M11 & $90 \mathrm{~s}$ & $\mathrm{~F}$ & + & - & $\begin{array}{l}\text { COVID-19; } \\
\text { Dementia }\end{array}$ & DLB \\
\hline C1 & $70 \mathrm{~s}$ & $\mathrm{M}$ & $\mathrm{N} / \mathrm{A}$ & $\mathrm{N} / \mathrm{A}$ & $\begin{array}{l}\text { Pneumonia; } \\
\text { No dementia or } \\
\text { parkinsonism }\end{array}$ & None \\
\hline C2 & $80 \mathrm{~s}$ & $\mathrm{M}$ & $\mathrm{N} / \mathrm{A}$ & $\mathrm{N} / \mathrm{A}$ & $\begin{array}{l}\text { Pneumonia; } \\
\text { No dementia or } \\
\text { parkinsonism }\end{array}$ & None \\
\hline C3 & $70 \mathrm{~s}$ & $F$ & $\mathrm{~N} / \mathrm{A}$ & $\mathrm{N} / \mathrm{A}$ & $\begin{array}{l}\text { No pneumonia; } \\
\text { No dementia or } \\
\text { parkinsonism }\end{array}$ & None \\
\hline $\mathrm{C} 4$ & $90 \mathrm{~s}$ & $\mathrm{M}$ & $\mathrm{N} / \mathrm{A}$ & $\mathrm{N} / \mathrm{A}$ & $\begin{array}{l}\text { Pneumonia; } \\
\text { No dementia or } \\
\text { parkinsonism }\end{array}$ & None \\
\hline C5 & $80 s$ & $\mathrm{~F}$ & $\mathrm{~N} / \mathrm{A}$ & $\mathrm{N} / \mathrm{A}$ & $\begin{array}{l}\text { No pneumonia; } \\
\text { No dementia or } \\
\text { parkinsonism }\end{array}$ & None \\
\hline $\mathrm{C} 6$ & $90 \mathrm{~s}$ & $F$ & $\mathrm{~N} / \mathrm{A}$ & $\mathrm{N} / \mathrm{A}$ & $\begin{array}{l}\text { No pneumonia; } \\
\text { No dementia or } \\
\text { parkinsonism }\end{array}$ & None \\
\hline C7 & $100 \mathrm{~s}$ & $\mathrm{M}$ & $\mathrm{N} / \mathrm{A}$ & $\mathrm{N} / \mathrm{A}$ & $\begin{array}{l}\text { Pneumonia; } \\
\text { No dementia or } \\
\text { parkinsonism }\end{array}$ & None \\
\hline C8 & $70 \mathrm{~s}$ & $F$ & $\mathrm{~N} / \mathrm{A}$ & N/A & $\begin{array}{l}\text { No pneumonia; } \\
\text { No dementia or } \\
\text { parkinsonism }\end{array}$ & None \\
\hline C9 & $80 \mathrm{~s}$ & $\mathrm{M}$ & $\mathrm{N} / \mathrm{A}$ & N/A & $\begin{array}{l}\text { Pneumonia; } \\
\text { Dementia }\end{array}$ & $A D$ \\
\hline C10 & $70 \mathrm{~s}$ & $\mathrm{M}$ & $\mathrm{N} / \mathrm{A}$ & $\mathrm{N} / \mathrm{A}$ & $\begin{array}{l}\text { No pneumonia; } \\
\text { No dementia or } \\
\text { parkinsonism }\end{array}$ & None \\
\hline C11 & $70 \mathrm{~s}$ & $M$ & $\mathrm{~N} / \mathrm{A}$ & $\mathrm{N} / \mathrm{A}$ & $\begin{array}{c}\text { Pneumonia; } \\
\text { Dementia; Parkinsonism }\end{array}$ & AD; PD \\
\hline C12 & $70 \mathrm{~s}$ & $\mathrm{M}$ & $\mathrm{N} / \mathrm{A}$ & $\mathrm{N} / \mathrm{A}$ & $\begin{array}{c}\text { Pneumonia; } \\
\text { Dementia; Parkinsonism }\end{array}$ & AD; PD \\
\hline C13 & $80 \mathrm{~s}$ & $F$ & $\mathrm{~N} / \mathrm{A}$ & $\mathrm{N} / \mathrm{A}$ & $\begin{array}{c}\text { Pneumonia; } \\
\text { Dementia; Parkinsonism }\end{array}$ & AD; PD \\
\hline C14 & $80 s$ & $M$ & $\mathrm{~N} / \mathrm{A}$ & N/A & $\begin{array}{l}\text { Pneumonia; } \\
\text { Dementia }\end{array}$ & $A D$ \\
\hline C15 & $90 \mathrm{~s}$ & $\mathrm{M}$ & $\mathrm{N} / \mathrm{A}$ & $\mathrm{N} / \mathrm{A}$ & $\begin{array}{c}\text { No pneumonia; } \\
\text { Dementia }\end{array}$ & $A D ; V a D$ \\
\hline C16 & $80 \mathrm{~s}$ & $\mathrm{M}$ & $\mathrm{N} / \mathrm{A}$ & $\mathrm{N} / \mathrm{A}$ & $\begin{array}{c}\text { Pneumonia; } \\
\text { Dementia; Parkinsonism }\end{array}$ & PD \\
\hline C17 & $90 \mathrm{~s}$ & $\bar{F}$ & $\mathrm{~N} / \mathrm{A}$ & $\mathrm{N} / \mathrm{A}$ & $\begin{array}{c}\text { No pneumonia; } \\
\text { Dementia }\end{array}$ & AD \\
\hline C18 & $80 \mathrm{~s}$ & $\bar{F}$ & $\mathrm{~N} / \mathrm{A}$ & $\mathrm{N} / \mathrm{A}$ & $\begin{array}{l}\text { No pneumonia; } \\
\text { No dementia or } \\
\text { parkinsonism }\end{array}$ & None \\
\hline C19 & $90 \mathrm{~s}$ & $F$ & $\mathrm{~N} / \mathrm{A}$ & $\mathrm{N} / \mathrm{A}$ & $\begin{array}{c}\text { No pneumonia; } \\
\text { Dementia; Parkinsonism }\end{array}$ & $\begin{array}{l}\text { AD; PSP; HS; } \\
\text { FTLD-TDP; VaD }\end{array}$ \\
\hline C20 & $80 \mathrm{~s}$ & $F$ & $\mathrm{~N} / \mathrm{A}$ & $\mathrm{N} / \mathrm{A}$ & $\begin{array}{c}\text { No pneumonia; } \\
\text { Dementia; Parkinsonism }\end{array}$ & $\mathrm{AD}$ \\
\hline
\end{tabular}


Table 2. Summary of the WGCNA analysis, including number of genes, differential analysis between Covid+ and controls, enrichment of pathways and cell specific genes, and hub genes for each co-expression network.

\begin{tabular}{ccccccc}
\hline Module & Genes $(\mathbf{n})$ & $\begin{array}{c}\text { Direction } \\
\text { (Covid+ vs CTL) }\end{array}$ & Adj-p & Cell & Pathways & Hub Gene \\
\hline Black & 459 & DOWN & $1.7 \mathrm{E}-11$ & - & Ribosome/RNA metabolism & CLSTN1 \\
Red & 587 & UP & $1.7 \mathrm{E}-11$ & - & Cilium/Taste & DMTF1 \\
Purple & 223 & DOWN & $3.5 \mathrm{E}-06$ & - & Mitochondrion & PJA2 \\
Blue & 1,248 & UP & $3.4 \mathrm{E}-05$ & - & - & ZNF767P \\
Green & 726 & UP & $6.5 \mathrm{E}-04$ & End, Per & Development, Angiogenesis & COL1A2 \\
Midnightblue & 39 & DOWN & $6.5 \mathrm{E}-04$ & Ast & - & ENHO \\
Cyan & 59 & UP & $2.0 \mathrm{E}-03$ & - & - & BTBD19 \\
Yellow & 848 & DOWN & $3.1 \mathrm{E}-03$ & Ast, Oli & Vesicles & NEBL \\
Greenyellow & 105 & DOWN & $1.0 \mathrm{E}-02$ & Ex, In & Synaptic signaling & CNR1 \\
Turquoise & 1,904 & DOWN & $1.2 \mathrm{E}-02$ & Ex, In & Synaptic signaling & CAMK2B \\
Tan & 103 & UP & $1.5 \mathrm{E}-02$ & - & Interferon/Immune & PARP9 \\
Magenta & 244 & - & 0.134 & - & - & LOC100996573 \\
Salmon & 87 & - & 0.153 & - & Protein folding & DNAJB1 \\
Brown & 1,043 & - & 0.210 & Oli, Ast, Per & Development, Cytoskeleton & SORBS1 \\
Pink & 314 & - & 0.210 & Mic & Immune & NCKAP1L \\
\hline
\end{tabular}




\section{REFERENCES}

1. Yassin, A, Nawaiseh, M, Shaban, A, et al. Neurological manifestations and complications of coronavirus disease 2019 (COVID-19): a systematic review and meta-analysis. BMC Neurol. 2021; 21:138.

2. Varatharaj, A, Thomas, N, Ellul, MA, et al. Neurological and neuropsychiatric complications of COVID-19 in 153 patients: a UK-wide surveillance study. Lancet Psychiatry. 2020; 7:875-882.

3. Delamarre, L, Gollion, C, Grouteau, G, et al. COVID-19-associated acute necrotising encephalopathy successfully treated with steroids and polyvalent immunoglobulin with unusual IgG targeting the cerebral fibre network. J Neurol Neurosurg Psychiatry. 2020; 91:1004-1006.

4. Ghannam, M, Alshaer, Q, Al-Chalabi, M, et al. Neurological involvement of coronavirus disease 2019: a systematic review. J Neurol. 2020; 267:3135-3153.

5. Anand, PZLBNHDHGDMC-AAM. Neurologic Findings Among Inpatients with COVID-19 at a Safety-Net U.S. Hospital. Neurology Clin Practive. 2020; In press.

6. Kremer, S, Lersy, F, de, SJ, et al. Brain MRI Findings in Severe COVID-19: A Retrospective Observational Study. Radiology. 2020; 297:E242-E251.

7. Pons-Escoda, A, Naval-Baudin, P, Majos, C, et al. Neurologic Involvement in COVID19: Cause or Coincidence? A Neuroimaging Perspective. AJNR Am J Neuroradiol. 2020; 41:1365-1369.

8. Romero-Sanchez, CM, Diaz-Maroto, I, Fernandez-Diaz, E, et al. Neurologic manifestations in hospitalized patients with COVID-19: The ALBACOVID registry. Neurology. 2020; 95:e1060-e1070.

9. Ellul, MA, Benjamin, L, Singh, B, et al. Neurological associations of COVID-19. Lancet Neurol. 2020; 19:767-783.

10. Guerrero, JI, Barragan, LA, Martinez, JD, et al. Central and peripheral nervous system involvement by COVID-19: a systematic review of the pathophysiology, clinical manifestations, neuropathology, neuroimaging, electrophysiology, and cerebrospinal fluid findings. BMC Infect Dis. 2021; 21:515.

11. Deigendesch, N, Sironi, L, Kutza, M, et al. Correlates of critical illness-related encephalopathy predominate postmortem COVID-19 neuropathology. Acta Neuropathol. 2020; 140:583-586.

12. $\mathrm{Wu}, \mathrm{Y}, \mathrm{Xu}, \mathrm{X}$, Chen, $\mathrm{Z}$, et al. Nervous system involvement after infection with COVID-19 and other coronaviruses. Brain Behav Immun. 2020.

13. $\mathrm{Gu}, \mathrm{J}$ and Korteweg, C. Pathology and pathogenesis of severe acute respiratory syndrome. Am J Pathol. 2007; 170:1136-1147. 
14. Baig, AM, Khaleeq, A, Ali, U, et al. Evidence of the COVID-19 Virus Targeting the CNS: Tissue Distribution, Host-Virus Interaction, and Proposed Neurotropic Mechanisms. ACS Chem Neurosci. 2020; 11:995-998.

15. Lapina, C, Rodic, M, Pechanski, D, et al. The potential genetic network of human brain SARS-CoV-2 infection. BIORXIV. 2020; https://doi.org/10.1101/2020.04.06.027318.

16. McCray, PB, Jr., Pewe, L, Wohlford-Lenane, C, et al. Lethal infection of K18-hACE2 mice infected with severe acute respiratory syndrome coronavirus. J Virol. 2007; 81:813-821.

17. Ding, Y, He, L, Zhang, Q, et al. Organ distribution of severe acute respiratory syndrome (SARS) associated coronavirus (SARS-CoV) in SARS patients: implications for pathogenesis and virus transmission pathways. J Pathol. 2004; 203:622-630.

18. Gu, J, Gong, E, Zhang, B, et al. Multiple organ infection and the pathogenesis of SARS. J Exp Med. 2005; 202:415-424.

19. Xu, J, Zhong, S, Liu, J, et al. Detection of severe acute respiratory syndrome coronavirus in the brain: potential role of the chemokine mig in pathogenesis. Clin Infect Dis. 2005; 41:1089-1096.

20. Netland, J, Meyerholz, DK, Moore, S, et al. Severe acute respiratory syndrome coronavirus infection causes neuronal death in the absence of encephalitis in mice transgenic for human ACE2. J Virol. 2008; 82:7264-7275.

21. Li, K, Wohlford-Lenane, C, Perlman, S, et al. Middle East Respiratory Syndrome Coronavirus Causes Multiple Organ Damage and Lethal Disease in Mice Transgenic for Human Dipeptidyl Peptidase 4. J Infect Dis. 2016; 213:712-722.

22. Hung, EC, Chim, SS, Chan, PK, et al. Detection of SARS coronavirus RNA in the cerebrospinal fluid of a patient with severe acute respiratory syndrome. Clin Chem. 2003; 49:2108-2109.

23. Nilsson, A, Edner, N, Albert, J, et al. Fatal encephalitis associated with coronavirus OC43 in an immunocompromised child. Infect Dis (Lond ). 2020;1-4.

24. Yeh, EA, Collins, A, Cohen, ME, et al. Detection of coronavirus in the central nervous system of a child with acute disseminated encephalomyelitis. Pediatrics. 2004; 113:e73-e76.

25. Morfopoulou, S, Brown, JR, Davies, EG, et al. Human Coronavirus OC43 Associated with Fatal Encephalitis. N Engl J Med. 2016; 375:497-498.

26. Murray, RS, Cai, GY, Hoel, K, et al. Coronavirus infects and causes demyelination in primate central nervous system. Virology. 1992; 188:274-284.

27. Wege, $\mathrm{H}$, Winter, J, Korner, $\mathrm{H}$, et al. Coronavirus induced demyelinating encephalomyelitis in rats: immunopathological aspects of viral persistency. Adv Exp Med Biol. 1990; 276:637-645. 
28. Jacomy, H, St-Jean, JR, Brison, E, et al. Mutations in the spike glycoprotein of human coronavirus OC43 modulate disease in BALB/c mice from encephalitis to flaccid paralysis and demyelination. J Neurovirol. 2010; 16:279-293.

29. Bergmann, CC, Lane, TE, and Stohlman, SA. Coronavirus infection of the central nervous system: host-virus stand-off. Nat Rev Microbiol. 2006; 4:121-132.

30. Wang, FI, Stohlman, SA, and Fleming, JO. Demyelination induced by murine hepatitis virus JHM strain (MHV-4) is immunologically mediated. J Neuroimmunol. 1990; 30:31-41.

31. Trandem, K, Jin, Q, Weiss, KA, et al. Virally expressed interleukin-10 ameliorates acute encephalomyelitis and chronic demyelination in coronavirus-infected mice. J Virol. 2011; 85:6822-6831.

32. Arbour, N, Day, R, Newcombe, J, et al. Neuroinvasion by human respiratory coronaviruses. J Virol. 2000; 74:8913-8921.

33. Wege, H. Immunopathological aspects of coronavirus infections. Springer Semin Immunopathol. 1995; 17:133-148.

34. Houtman, JJ and Fleming, JO. Pathogenesis of mouse hepatitis virus-induced demyelination. J Neurovirol. 1996; 2:361-376.

35. Cabirac, GF, Soike, KF, Zhang, JY, et al. Entry of coronavirus into primate CNS following peripheral infection. Microb Pathog. 1994; 16:349-357.

36. Cabirac, GF, Murray, RS, McLaughlin, LB, et al. In vitro interaction of coronaviruses with primate and human brain microvascular endothelial cells. Adv Exp Med Biol. 1995; 380:7988.

37. Murray, RS, Cai, GY, Soike, KF, et al. Further observations on coronavirus infection of primate CNS. J Neurovirol. 1997; 3:71-75.

38. Murray, RS, Cai, GY, Hoel, K, et al. Coronavirus infects and causes demyelination in primate central nervous system. Virology. 1992; 188:274-284.

39. Thakur, KT, Miller, EH, Glendinning, MD, et al. COVID-19 neuropathology at Columbia University Irving Medical Center/New York Presbyterian Hospital. Brain. 2021.

40. Bhatnagar, J, Gary, J, Reagan-Steiner, S, et al. Evidence of Severe Acute Respiratory Syndrome Coronavirus 2 Replication and Tropism in the Lungs, Airways, and Vascular Endothelium of Patients With Fatal Coronavirus Disease 2019: An Autopsy Case Series. J Infect Dis. 2021; 223:752-764.

41. Roden, AC, Vrana, JA, Koepplin, JW, et al. Comparison of In Situ Hybridization, Immunohistochemistry, and Reverse Transcription-Droplet Digital Polymerase Chain Reaction for Severe Acute Respiratory Syndrome Coronavirus 2 (SARS-CoV-2) Testing in Tissue. Arch Pathol Lab Med. 2021; 145:785-796.

42. Sablone, S, Solarino, B, Ferorelli, D, et al. Post-mortem persistence of SARS-CoV-2: a preliminary study. Forensic Sci Med Pathol. 2021. 
medRxiv preprint doi: https://doi.org/10.1101/2021.09.12.21263291; this version posted September 15, 2021. The copyright holder for this preprint (which was not certified by peer review) is the author/funder, who has granted medRxiv a license to display the preprint in perpetuity.

It is made available under a CC-BY-ND 4.0 International license .

43. Skok, K, Stelzl, E, Trauner, M, et al. Post-mortem viral dynamics and tropism in COVID19 patients in correlation with organ damage. Virchows Arch. 2020.

44. Deinhardt-Emmer, S, Wittschieber, D, Sanft, J, et al. Early postmortem mapping of SARS-CoV-2 RNA in patients with COVID-19 and correlation to tissue damage. bioRxiv. 2020;2020.

45. Bihlmaier, K, Coras, R, Willam, C, et al. Disseminated Multifocal Intracerebral Bleeding Events in Three Coronavirus Disease 2019 Patients on Extracorporeal Membrane Oxygenation As Rescue Therapy. Crit Care Explor. 2020; 2:e0218.

46. Freij, BJ, Gebara, BM, Tariq, R, et al. Fatal central nervous system co-infection with SARS-CoV-2 and tuberculosis in a healthy child. BMC Pediatr. 2020; 20:429.

47. Matschke, J, Lutgehetmann, M, Hagel, C, et al. Neuropathology of patients with COVID19 in Germany: a post-mortem case series. Lancet Neurol. 2020; 19:919-929.

48. Wichmann, D, Sperhake, JP, Lutgehetmann, M, et al. Autopsy Findings and Venous Thromboembolism in Patients With COVID-19: A Prospective Cohort Study. Ann Intern Med. 2020; 173:268-277.

49. Paniz-Mondolfi, A, Bryce, C, Grimes, Z, et al. Central nervous system involvement by severe acute respiratory syndrome coronavirus-2 (SARS-CoV-2). J Med Virol. 2020; 92:699702.

50. Menter, T, Haslbauer, JD, Nienhold, R, et al. Postmortem examination of COVID-19 patients reveals diffuse alveolar damage with severe capillary congestion and variegated findings in lungs and other organs suggesting vascular dysfunction. Histopathology. 2020; 77:198-209.

51. Al-Sarraj, S, Troakes, C, Hanley, B, et al. Invited Review: The spectrum of neuropathology in COVID-19. Neuropathol Appl Neurobiol. 2020.

52. Jensen, MP, Le, QJ, Officer-Jones, L, et al. Neuropathological findings in two patients with fatal COVID-19. Neuropathol Appl Neurobiol. 2020.

53. Kantonen, J, Mahzabin, S, Mayranpaa, MI, et al. Neuropathologic features of four autopsied COVID-19 patients. Brain Pathol. 2020; 30:1012-1016.

54. Meinhardt, J, Radke, J, Dittmayer, C, et al. Olfactory transmucosal SARS-CoV-2 invasion as a port of central nervous system entry in individuals with COVID-19. Nat Neurosci. 2020.

55. Puelles, VG, Lutgehetmann, M, Lindenmeyer, MT, et al. Multiorgan and Renal Tropism of SARS-CoV-2. N Engl J Med. 2020; 383:590-592.

56. Remmelink, M, De, MR, D'Haene, N, et al. Unspecific post-mortem findings despite multiorgan viral spread in COVID-19 patients. Crit Care. 2020; 24:495.

57. Solomon, IH, Normandin, E, Bhattacharyya, S, et al. Neuropathological Features of Covid-19. N Engl J Med. 2020; 383:989-992. 
58. Lopez, G, Tonello, C, Osipova, G, et al. Olfactory bulb SARS-CoV-2 infection is not paralleled by the presence of virus in other central nervous system areas. Neuropathol Appl Neurobiol. 2021.

59. Hur, KH, Park, K, Lim, Y, et al. Evaluation of Four Commercial Kits for SARS-CoV-2 Real-Time Reverse-Transcription Polymerase Chain Reaction Approved by Emergency-UseAuthorization in Korea. Front Med (Lausanne ). 2020; 7:521.

60. Barra, GB, Santa Rita, TH, Mesquita, PG, et al. Analytical Sensitivity and Specificity of Two RT-qPCR Protocols for SARS-CoV-2 Detection Performed in an Automated Workflow. Genes (Basel ). 2020; 11.

61. Wolfel, R, Corman, VM, Guggemos, W, et al. Virological assessment of hospitalized patients with COVID-2019. Nature. 2020; 581:465-469.

62. El Jamal, SM, Pujadas, E, Ramos, I, et al. Tissue-based SARS-CoV-2 detection in fatal COVID-19 infections: Sustained direct viral-induced damage is not necessary to drive disease progression. Hum Pathol. 2021; 114:110-119.

63. Lima, M, Siokas, V, Aloizou, AM, et al. Unraveling the Possible Routes of SARS-COV-2 Invasion into the Central Nervous System. Curr Treat Options Neurol. 2020; 22:37.

64. Bhatta, S, Sharma, D, Sharma, S, et al. Smell and Taste Disturbance in COVID-19 Patients: A Prospective Multicenteric Review. Indian J Otolaryngol Head Neck Surg. 2021;1-7.

65. Xydakis, MS, Albers, MW, Holbrook, EH, et al. Post-viral effects of COVID-19 in the olfactory system and their implications. Lancet Neurol. 2021; 20:753-761.

66. Levinson, R, Elbaz, M, Ben-Ami, R, et al. Anosmia and dysgeusia appeared early in third of our patients with mild SARS-CoV-2 infection and were short-lived in most patients. MEDRXIV. 2020; https://doi.org/10.1101/2020.04.11.20055483.

67. Eliezer, M, Hautefort, C, Hamel, AL, et al. Sudden and Complete Olfactory Loss Function as a Possible Symptom of COVID-19. JAMA Otolaryngol Head Neck Surg. 2020.

68. Cantuti-Castelvetri, L, Ojha, R, Pedro, LD, et al. Neuropilin-1 facilitates SARS-CoV-2 cell entry and infectivity. Science. 2020; 370:856-860.

69. Kabbani, N and Olds, JL. Does COVID19 infect the brain? If so, smokers might be at a higher risk. Mol Pharmacol. 2020.

70. Butowt, R and Bilinska, K. SARS-CoV-2: Olfaction, Brain Infection, and the Urgent Need for Clinical Samples Allowing Earlier Virus Detection. ACS Chem Neurosci. 2020.

71. Hawrylycz, MJ, Lein, ES, Guillozet-Bongaarts, AL, et al. An anatomically comprehensive atlas of the adult human brain transcriptome. Nature. 2012; 489:391-399.

72. Serrano, GE, Walker, JE, Arce, R, et al. Mapping of SARS-CoV-2 Brain Invasion and Histopathology in COVID-19 Disease. medRxiv. 2021. 
medRxiv preprint doi: https://doi.org/10.1101/2021.09.12.21263291; this version posted September 15, 2021. The copyright holder for this preprint (which was not certified by peer review) is the author/funder, who has granted medRxiv a license to display the preprint in perpetuity.

It is made available under a CC-BY-ND 4.0 International license .

73. Lee, MH, Perl, DP, Nair, G, et al. Microvascular Injury in the Brains of Patients with Covid-19. N Engl J Med. 2020.

74. Pilotto, A, Odolini, S, Masciocchi, S, et al. Steroid-Responsive Encephalitis in Coronavirus Disease 2019. Ann Neurol. 2020; 88:423-427.

75. Poyiadji, N, Shahin, G, Noujaim, D, et al. COVID-19-associated Acute Hemorrhagic Necrotizing Encephalopathy: CT and MRI Features. Radiology. 2020;201187.

76. Moriguchi, T, Harii, N, Goto, J, et al. A first Case of Meningitis/Encephalitis associated with SARS-Coronavirus-2. Int J Infect Dis. 2020.

77. Mao, L, Jin, H, Wang, M, et al. Neurologic Manifestations of Hospitalized Patients With Coronavirus Disease 2019 in Wuhan, China. JAMA Neurol. 2020.

78. von Weyhern, $\mathrm{CH}$, Kaufmann, I, Neff, F, et al. Early evidence of pronounced brain involvement in fatal COVID-19 outcomes. Lancet. 2020; 395:e109.

79. Ludlow, M, Kortekaas, J, Herden, C, et al. Neurotropic virus infections as the cause of immediate and delayed neuropathology. Acta Neuropathol. 2016; 131:159-184.

80. Seilhean, D. Infections of the central nervous system: Neuropathology. Rev Neurol (Paris). 2019; 175:431-435.

81. Keller, E, Brandi, G, Winklhofer, S, et al. Large and Small Cerebral Vessel Involvement in Severe COVID-19: Detailed Clinical Workup of a Case Series. Stroke. 2020; 51:3719-3722.

82. Bradley, BT, Maioli, H, Johnston, R, et al. Histopathology and ultrastructural findings of fatal COVID-19 infections in Washington State: a case series. Lancet. 2020; 396:320-332.

83. Borczuk, AC, Salvatore, SP, Seshan, SV, et al. COVID-19 pulmonary pathology: a multi-institutional autopsy cohort from Italy and New York City. Mod Pathol. 2020; 33:21562168.

84. Reichard, RR, Kashani, KB, Boire, NA, et al. Neuropathology of COVID-19: a spectrum of vascular and acute disseminated encephalomyelitis (ADEM)-like pathology. Acta Neuropathol. 2020; 140:1-6.

85. Al-Dalahmah, O, Thakur, KT, Nordvig, AS, et al. Neuronophagia and microglial nodules in a SARS-CoV-2 patient with cerebellar hemorrhage. Acta Neuropathol Commun. 2020; 8:147.

86. Conklin, J, Frosch, MP, Mukerji, S, et al. Cerebral Microvascular Injury in Severe COVID-19. medRxiv. 2020.

87. Jaunmuktane, Z, Mahadeva, U, Green, A, et al. Microvascular injury and hypoxic damage: emerging neuropathological signatures in COVID-19. Acta Neuropathol. 2020; 140:397-400.

88. Song, E, Zhang, C, Israelow, B, et al. Neuroinvasion of SARS-CoV-2 in human and mouse brain. bioRxiv. 2020. 
89. Beach, TG, Sue, LI, Intorcia, AJ, et al. Acute Brain Ischemia, Infarction and Hemorrhage in Subjects Dying with or Without Autopsy-Proven Acute Pneumonia. medRxiv. 2021.

90. Piroth, L, Cottenet, J, Mariet, AS, et al. Comparison of the characteristics, morbidity, and mortality of COVID-19 and seasonal influenza: a nationwide, population-based retrospective cohort study. Lancet Respir Med. 2020.

91. Nannoni, S, de, GR, Bell, S, et al. Stroke in COVID-19: A systematic review and metaanalysis. Int J Stroke. 2021; 16:137-149.

92. Bryce, C, Grimes, Z, Pujadas, E, et al. Pathophysiology of SARS-CoV-2: targeting of endothelial cells renders a complex disease with thrombotic microangiopathy and aberrant immune response. The Mount Sinai COVID-19 autopsy experience. medRxiv. 2020;2020.

93. Coolen, T, Lolli, V, Sadeghi, N, et al. Early postmortem brain MRI findings in COVID-19 non-survivors. Neurology. 2020; 95:e2016-e2027.

94. Kirschenbaum, D, Imbach, LL, Rushing, EJ, et al. Intracerebral endotheliitis and microbleeds are neuropathological features of COVID-19. Neuropathol Appl Neurobiol. 2020.

95. Radmanesh, A, Raz, E, Zan, E, et al. Brain Imaging Use and Findings in COVID-19: A Single Academic Center Experience in the Epicenter of Disease in the United States. AJNR Am J Neuroradiol. 2020; 41:1179-1183.

96. Beyrouti, R, Best, JG, Chandratheva, A, et al. Characteristics of intracerebral haemorrhage associated with COVID-19: a systematic review and pooled analysis of individual patient and aggregate data. J Neurol. 2021.

97. Beyrouti, R, Adams, ME, Benjamin, L, et al. Characteristics of ischaemic stroke associated with COVID-19. J Neurol Neurosurg Psychiatry. 2020; 91:889-891.

98. Diener, HC, Berlit, P, and Masjuan, J. COVID-19: patients with stroke or risk of stroke. Eur Heart J Suppl. 2020; 22:25-28.

99. Merkler, AE, Parikh, NS, Mir, S, et al. Risk of Ischemic Stroke in Patients With Coronavirus Disease 2019 (COVID-19) vs Patients With Influenza. JAMA Neurol. 2020.

100. Nersesjan, V, Amiri, M, Christensen, HK, et al. Thirty-Day Mortality and Morbidity in COVID-19 Positive vs. COVID-19 Negative Individuals and vs. Individuals Tested for Influenza A/B: A Population-Based Study. Front Med (Lausanne ). 2020; 7:598272.

101. Ramos-Araque, ME, Siegler, JE, Ribo, M, et al. Stroke etiologies in patients with COVID-19: the SVIN COVID-19 multinational registry. BMC Neurol. 2021; 21:43.

102. Rothstein, A, Oldridge, O, Schwennesen, $\mathrm{H}$, et al. Acute Cerebrovascular Events in Hospitalized COVID-19 Patients. Stroke. 2020; 51:e219-e222.

103. Siow, I, Lee, KS, Zhang, JJY, et al. Stroke as a Neurological Complication of COVID-19: A Systematic Review and Meta-Analysis of Incidence, Outcomes and Predictors. J Stroke Cerebrovasc Dis. 2021; 30:105549. 
104. Favreau, DJ, Desforges, M, St-Jean, JR, et al. A human coronavirus OC43 variant harboring persistence-associated mutations in the $S$ glycoprotein differentially induces the unfolded protein response in human neurons as compared to wild-type virus. Virology. 2009; 395:255-267.

105. Dobin, A, Davis, CA, Schlesinger, F, et al. STAR: ultrafast universal RNA-seq aligner. Bioinformatics. 2013; 29:15-21.

106. Ewels, P, Magnusson, M, Lundin, S, et al. MultiQC: summarize analysis results for multiple tools and samples in a single report. Bioinformatics. 2016; 32:3047-3048.

107. Mathys, H, Davila-Velderrain, J, Peng, Z, et al. Single-cell transcriptomic analysis of Alzheimer's disease. Nature. 2019; 570:332-337.

108. Satija, R, Farrell, JA, Gennert, D, et al. Spatial reconstruction of single-cell gene expression data. Nat Biotechnol. 2015; 33:495-502.

109. Langfelder, $\mathrm{P}$ and Horvath, S. WGCNA: an R package for weighted correlation network analysis. BMC Bioinformatics. 2008; 9:559.

110. Law, CW, Chen, Y, Shi, W, et al. voom: Precision weights unlock linear model analysis tools for RNA-seq read counts. Genome Biol. 2014; 15:R29.

111. Ritchie, ME, Phipson, B, Wu, D, et al. limma powers differential expression analyses for RNA-sequencing and microarray studies. Nucleic Acids Res. 2015; $43: e 47$.

112. Zhang, B and Horvath, S. A general framework for weighted gene co-expression network analysis. Stat Appl Genet Mol Biol. 2005; 4:Article17.

113. Langfelder, $\mathrm{P}$ and Horvath, $\mathrm{S}$. Eigengene networks for studying the relationships between co-expression modules. BMC Syst Biol. 2007; 1:54.

114. Campbell, KR and Yau, C. Uncovering pseudotemporal trajectories with covariates from single cell and bulk expression data. Nat Commun. 2018; 9:2442.

115. Agyeman, AA, Chin, KL, Landersdorfer, CB, et al. Smell and Taste Dysfunction in Patients With COVID-19: A Systematic Review and Meta-analysis. Mayo Clin Proc. 2020; 95:1621-1631.

116. Vaira, LA, Salzano, G, Deiana, G, et al. Anosmia and Ageusia: Common Findings in COVID-19 Patients. Laryngoscope. 2020; 130:1787.

117. Redolfi, N and Lodovichi, C. Spontaneous Afferent Activity Carves Olfactory Circuits. Front Cell Neurosci. 2021; 15:637536.

118. de Melo, GD, Lazarini, F, Levallois, S, et al. COVID-19-related anosmia is associated with viral persistence and inflammation in human olfactory epithelium and brain infection in hamsters. Sci Transl Med. 2021; 13.

119. Iwata, $\mathrm{H}$, Goettsch, $\mathrm{C}$, Sharma, $\mathrm{A}$, et al. PARP9 and PARP14 cross-regulate macrophage activation via STAT1 ADP-ribosylation. Nat Commun. 2016; 7:12849. 
120. Zhang, Y, Mao, D, Roswit, WT, et al. PARP9-DTX3L ubiquitin ligase targets host histone $\mathrm{H} 2 \mathrm{BJ}$ and viral $3 \mathrm{C}$ protease to enhance interferon signaling and control viral infection. Nat Immunol. 2015; 16:1215-1227.

121. Russo, LC, Tomasin, R, Matos, IA, et al. The SARS-CoV-2 Nsp3 macrodomain reverses PARP9/DTX3L-dependent ADP-ribosylation induced by interferon signaling. J Biol Chem. 2021; 297:101041.

122. Amruta, N, Chastain, WH, Paz, M, et al. SARS-CoV-2 mediated neuroinflammation and the impact of COVID-19 in neurological disorders. Cytokine Growth Factor Rev. 2021; 58:1-15.

123. Yang, AC, Kern, F, Losada, PM, et al. Dysregulation of brain and choroid plexus cell types in severe COVID-19. Nature. 2021; 595:565-571.

124. Schwabenland, M, Salie, H, Tanevski, J, et al. Deep spatial profiling of human COVID19 brains reveals neuroinflammation with distinct microanatomical microglia-T-cell interactions. Immunity. 2021; 54:1594-1610.

125. Remy, KE, Mazer, M, Striker, DA, et al. Severe immunosuppression and not a cytokine storm characterizes COVID-19 infections. JCI Insight. 2020; 5.

126. Liu, C, Martins, AJ, Lau, WW, et al. Time-resolved systems immunology reveals a late juncture linked to fatal COVID-19. Cell. 2021; 184:1836-1857.

127. Lucas, C, Wong, P, Klein, J, et al. Longitudinal analyses reveal immunological misfiring in severe COVID-19. Nature. 2020; 584:463-469.

128. Luporini, RL, Rodolpho, JMA, Kubota, LT, et al. IL-6 and IL-10 are associated with disease severity and higher comorbidity in adults with COVID-19. Cytokine. 2021; 143:155507.

129. Boldrini, M, Canoll, PD, and Klein, RS. How COVID-19 Affects the Brain. JAMA Psychiatry. 2021; 78:682-683.

130. Daniels, BP, Holman, DW, Cruz-Orengo, L, et al. Viral pathogen-associated molecular patterns regulate blood-brain barrier integrity via competing innate cytokine signals. mBio. 2014; 5:e01476-14.

131. Liddelow, SA, Guttenplan, KA, Clarke, LE, et al. Neurotoxic reactive astrocytes are induced by activated microglia. Nature. 2017; 541:481-487.

132. Vasek, MJ, Garber, C, Dorsey, D, et al. A complement-microglial axis drives synapse loss during virus-induced memory impairment. Nature. 2016; 534:538-543.

133. Tahamtan, A, Tavakoli-Yaraki, M, Rygiel, TP, et al. Effects of cannabinoids and their receptors on viral infections. J Med Virol. 2016; 88:1-12.

134. Nicole, O and Pacary, E. CaMKIlbeta in Neuronal Development and Plasticity: An Emerging Candidate in Brain Diseases. Int J Mol Sci. 2020; 21. 
135. Kury, S, van Woerden, GM, Besnard, T, et al. De Novo Mutations in Protein Kinase Genes CAMK2A and CAMK2B Cause Intellectual Disability. Am J Hum Genet. 2017; 101:768788.

136. Akita, $\mathrm{T}$, Aoto, $\mathrm{K}$, Kato, $\mathrm{M}$, et al. De novo variants in CAMK2A and CAMK2B cause neurodevelopmental disorders. Ann Clin Transl Neurol. 2018; 5:280-296.

137. Rizzi, S, Spagnoli, C, Salerno, GG, et al. Severe intellectual disability, absence of language, epilepsy, microcephaly and progressive cerebellar atrophy related to the recurrent de novo variant $\mathrm{p} .(\mathrm{P} 139 \mathrm{~L})$ of the CAMK2B gene: $\mathrm{A}$ case report and brief review. Am J Med Genet A. $2020 ; 182: 2675-2679$.

138. Woo, MS, Malsy, J, Pottgen, J, et al. Frequent neurocognitive deficits after recovery from mild COVID-19. Brain Commun. 2020; 2:fcaa205.

139. Twardowski, T, Fertala, A, Orgel, JP, et al. Type I collagen and collagen mimetics as angiogenesis promoting superpolymers. Curr Pharm Des. 2007; 13:3608-3621.

140. Ostergaard, L. SARS CoV-2 related microvascular damage and symptoms during and after COVID-19: Consequences of capillary transit-time changes, tissue hypoxia and inflammation. Physiol Rep. 2021; 9:e14726.

141. Ackermann, M, Mentzer, SJ, Kolb, M, et al. Inflammation and intussusceptive angiogenesis in COVID-19: everything in and out of flow. Eur Respir J. 2020; 56. 
A

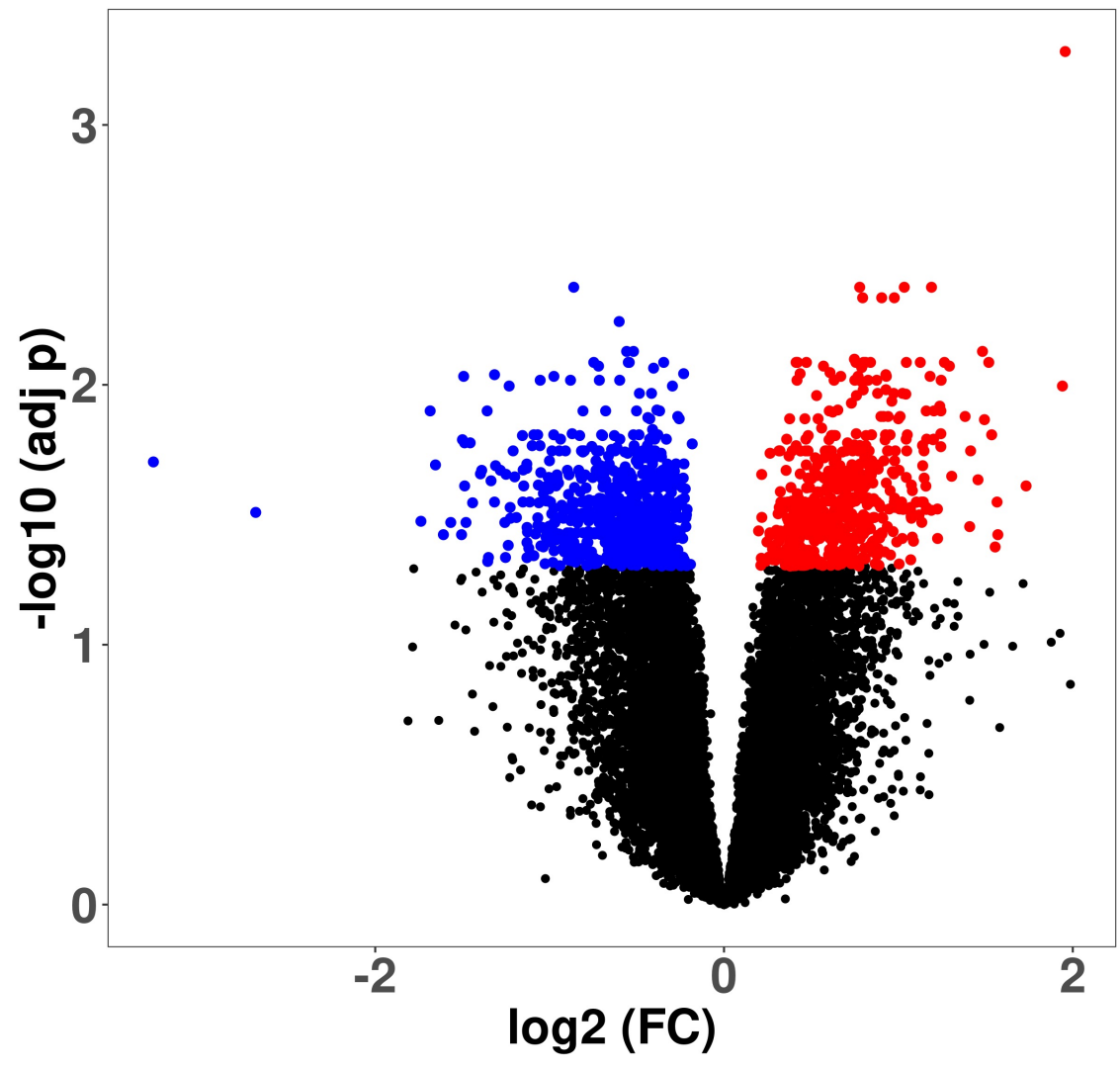

B

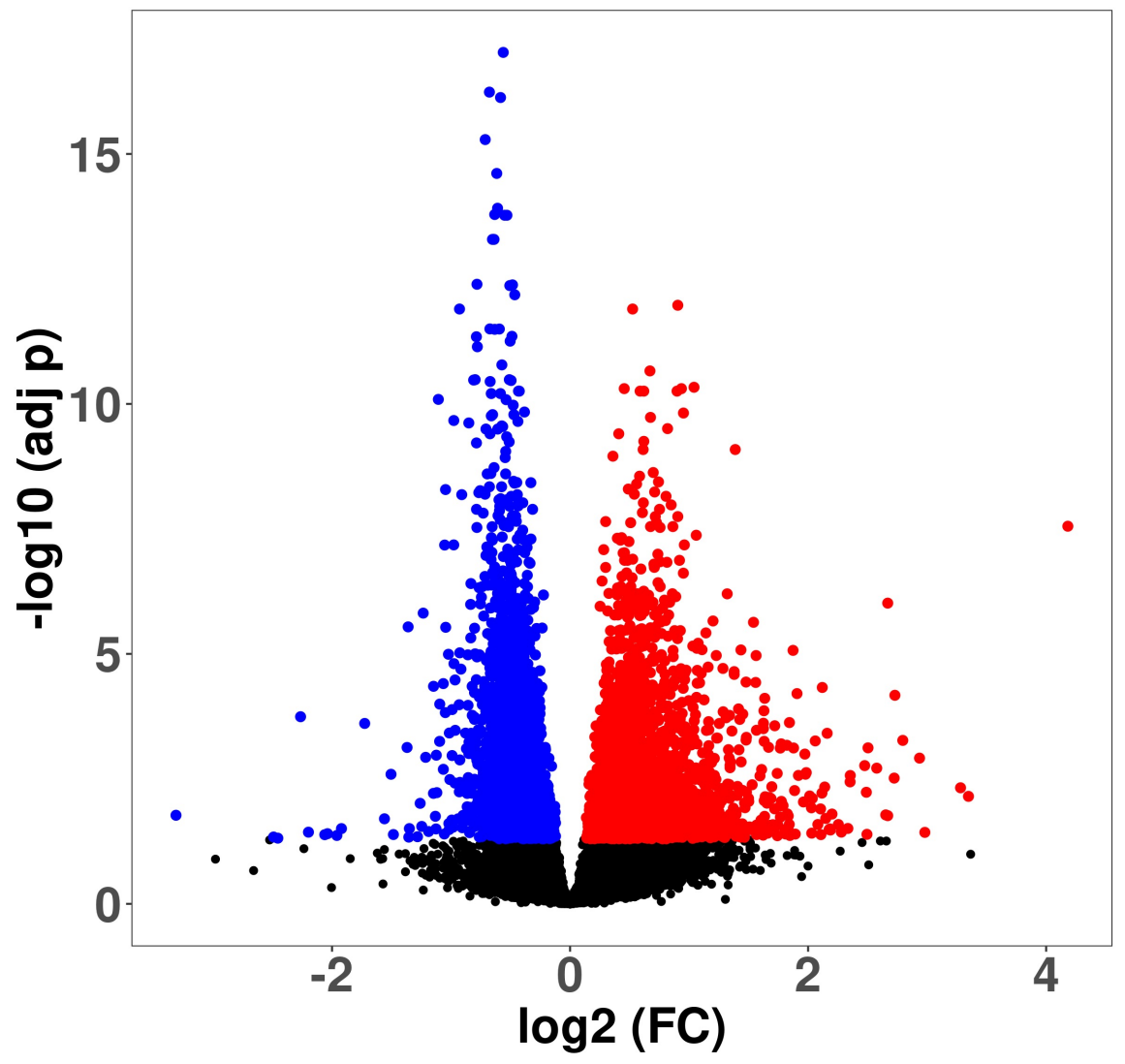

Figure 1. Volcano plot showing the differential expression analysis results after comparing Covid+ vs CTL in Amygdala (A) and Olfactory Bulb (B). Genes in blue and red were downregulated and upregulated in Covid+ patients (adj-p < 0.05). 

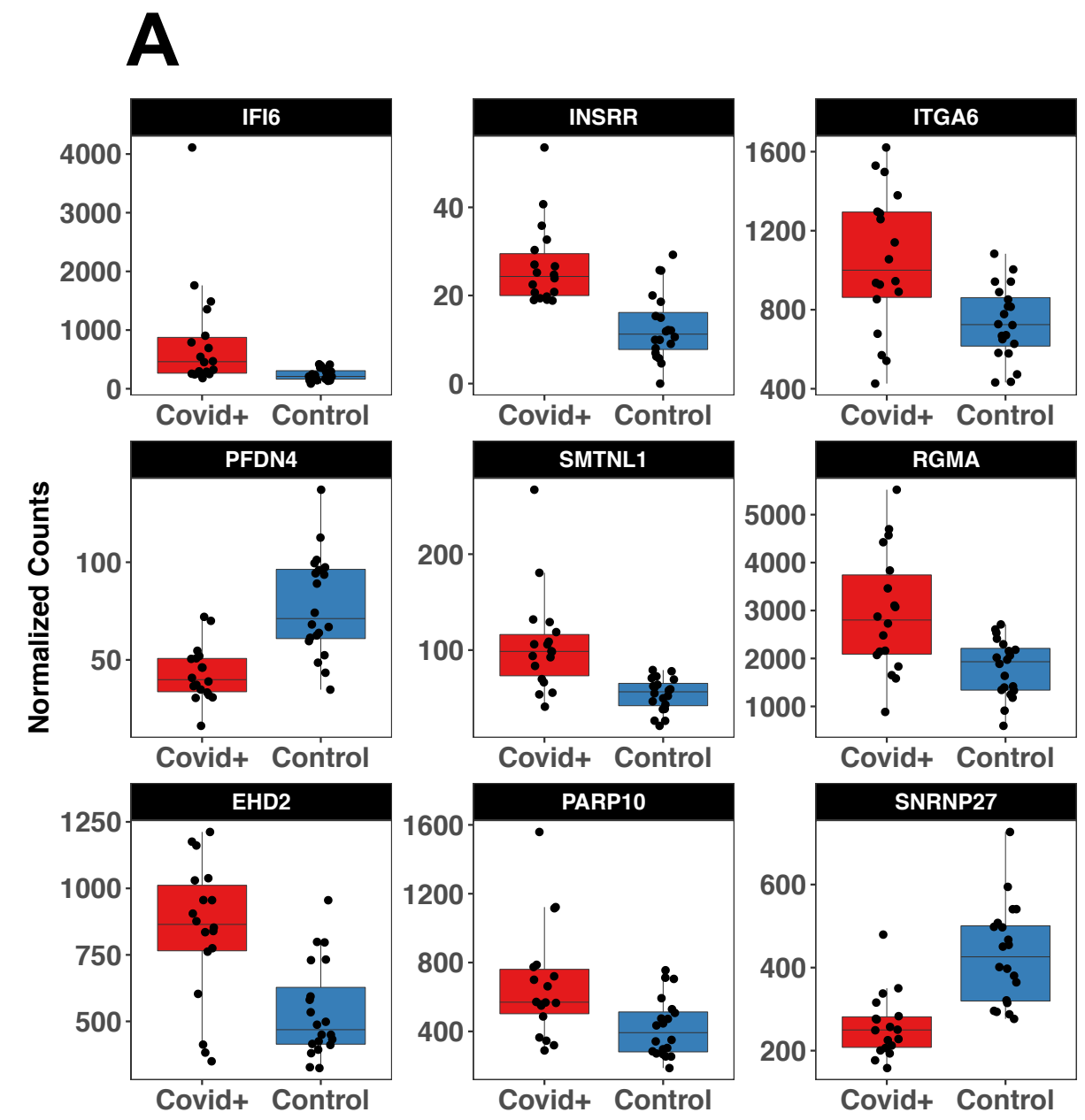

B
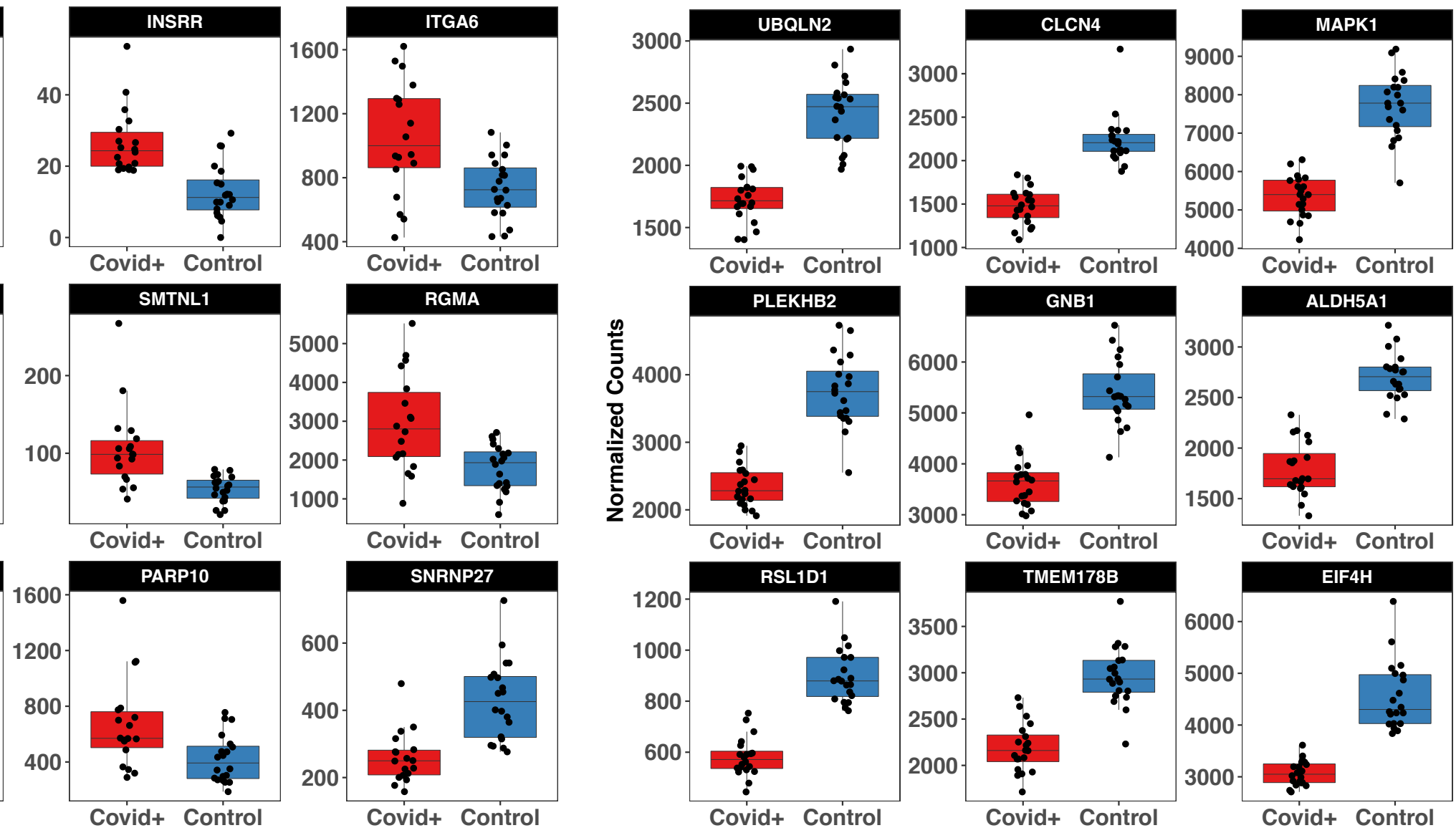

Figure 2. Top 9 genes differentially expressed in amygdala (A) and olfactory bulb (B) 


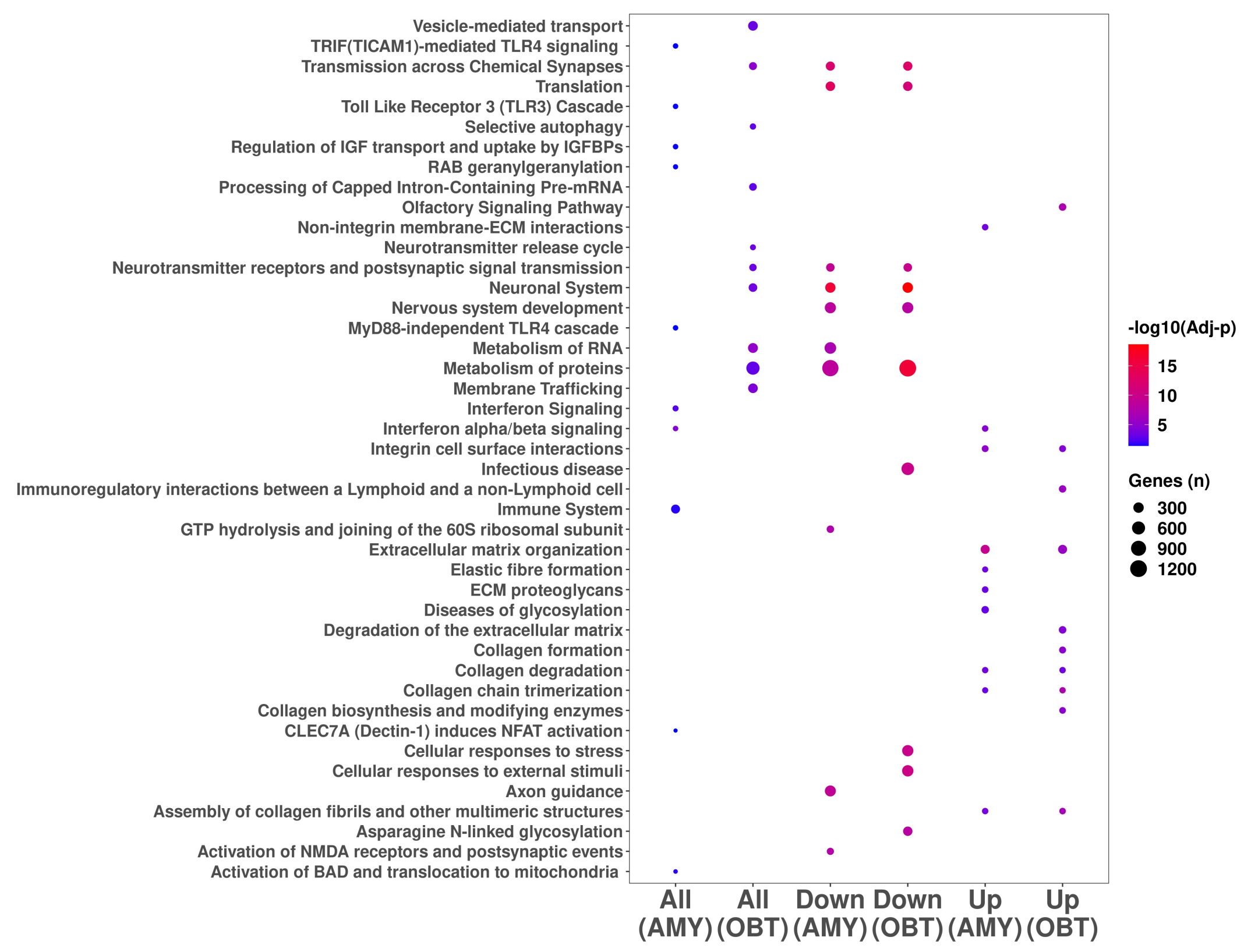

Figure 3. Top 10 pathways enriched in amygdala and olfactory bulb All: all DEGs; Up: DEGs upregulated in Covid+ patients; Down: DEGs downregulated in Covid+ patients 


\section{Amygdala}
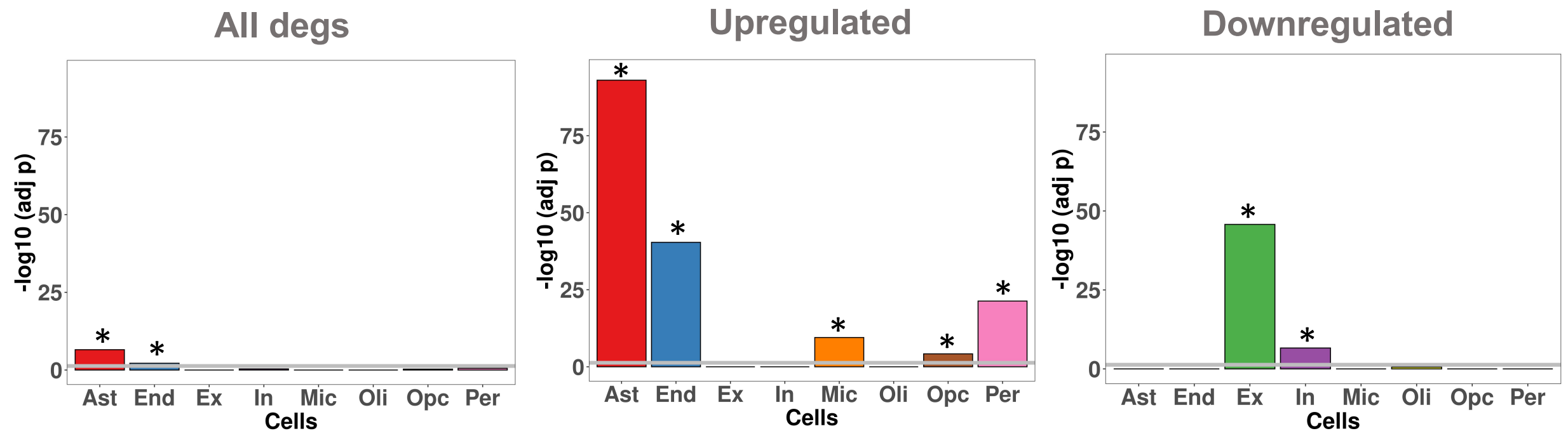

\section{Olfactory bulb}
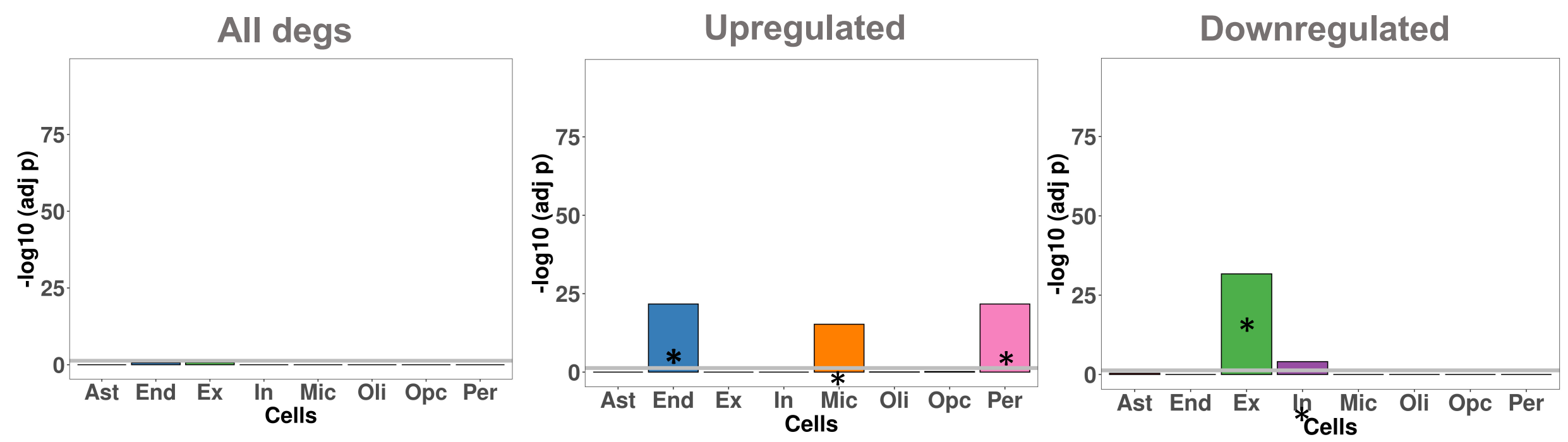

Figure 4. Cell specific genes enrichment in among DEGs in amygdala and olfactory bulb. Gene classes significantly enriched are indicate with the asterisk (FDR < 0.05) 


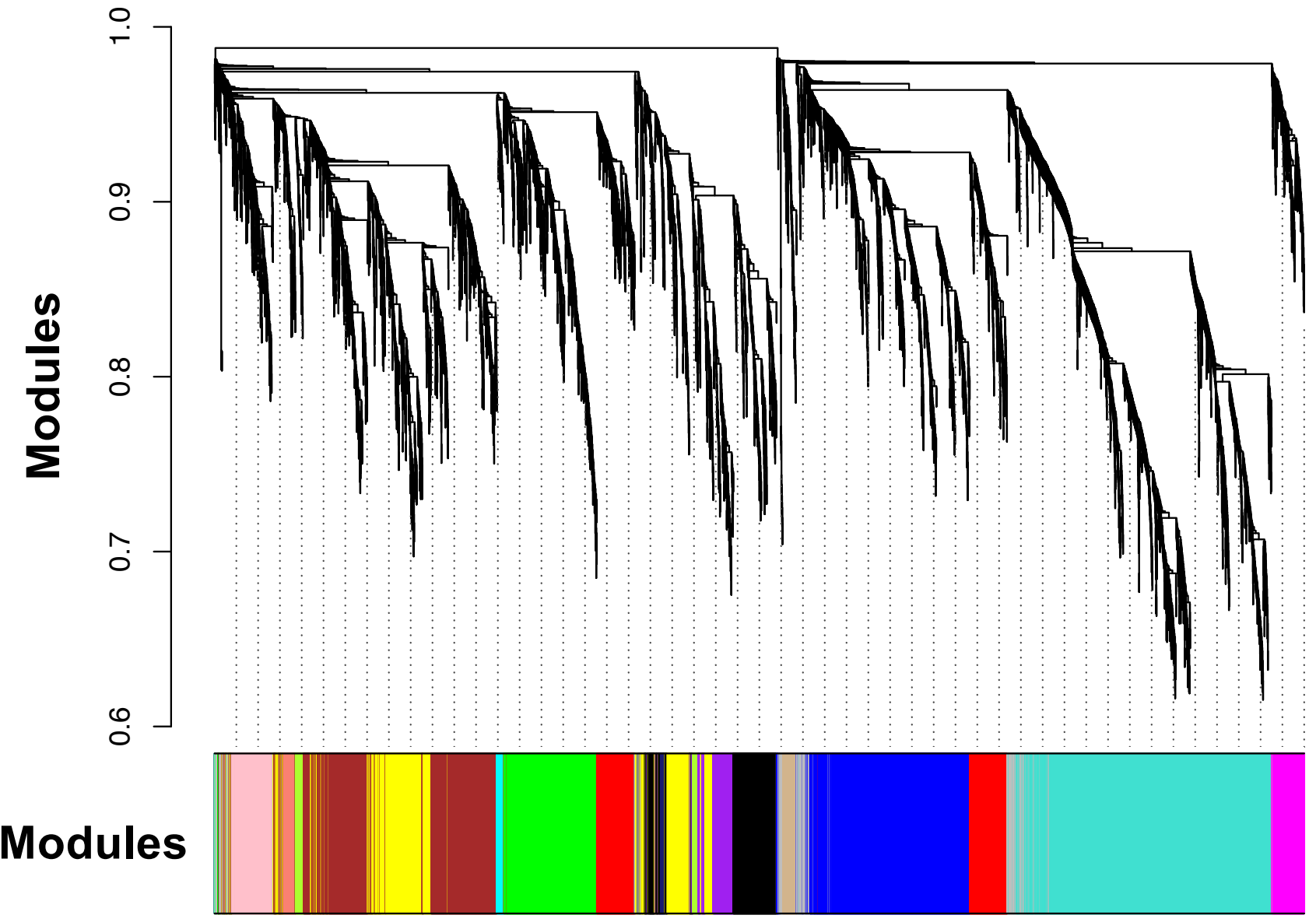

B

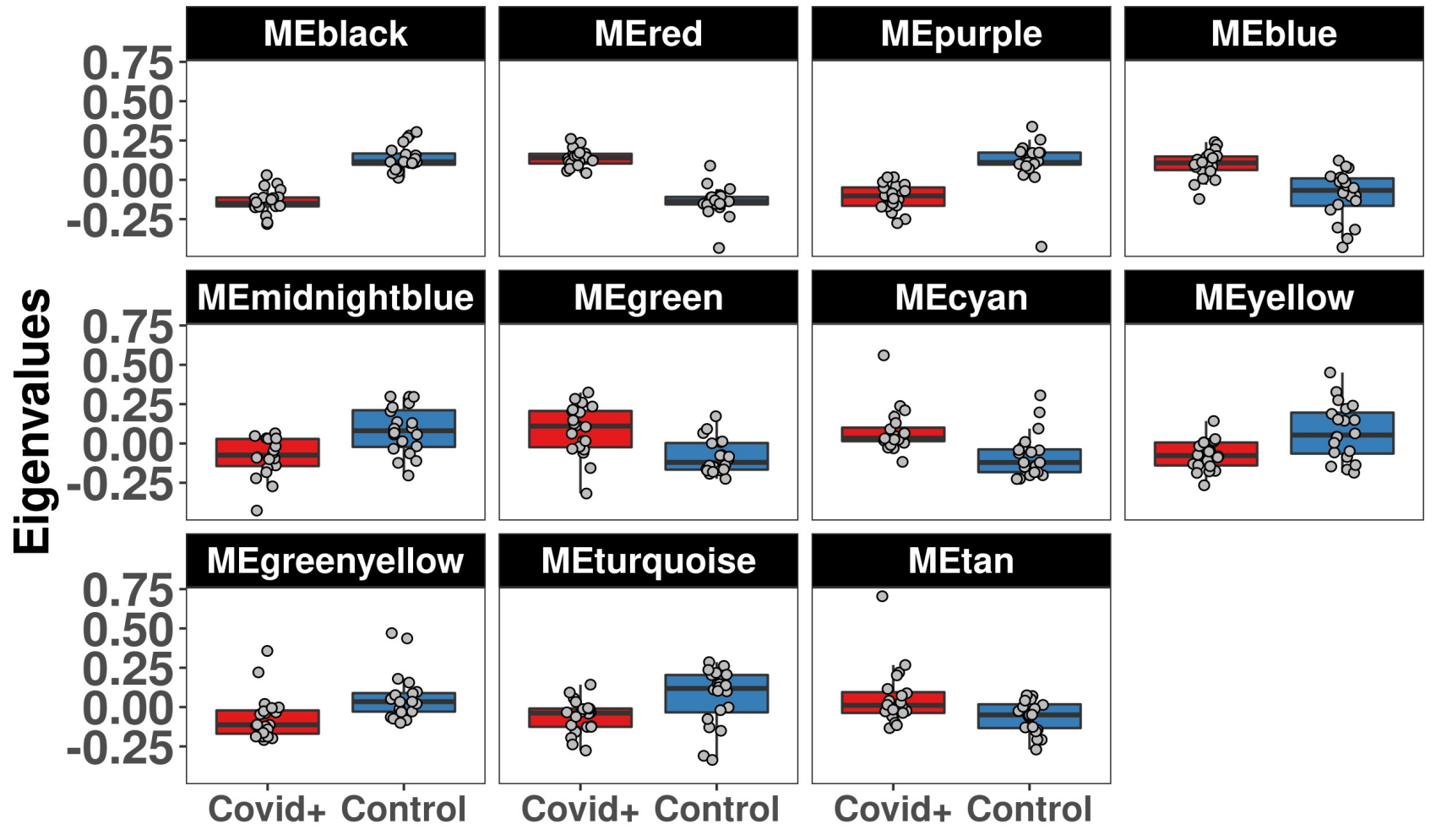

Figure 5. WGCNA analysis in olfactory bulb. We detected 15 coexpression modules $(A)$ including 11 differentially expressed between Covid+ and Controls (B) 
medRxiv preprint doi: https://doi.org/10.1101/2021.09.12.21263291; this version posted September 15, 2021. The copyright holder for this preprint (which was not certified by peer review) is the author/funder, who has granted medRxiv a license to display the preprint in perpetuity.

A

It is made available under a CC-BY-ND 4.0 International license .

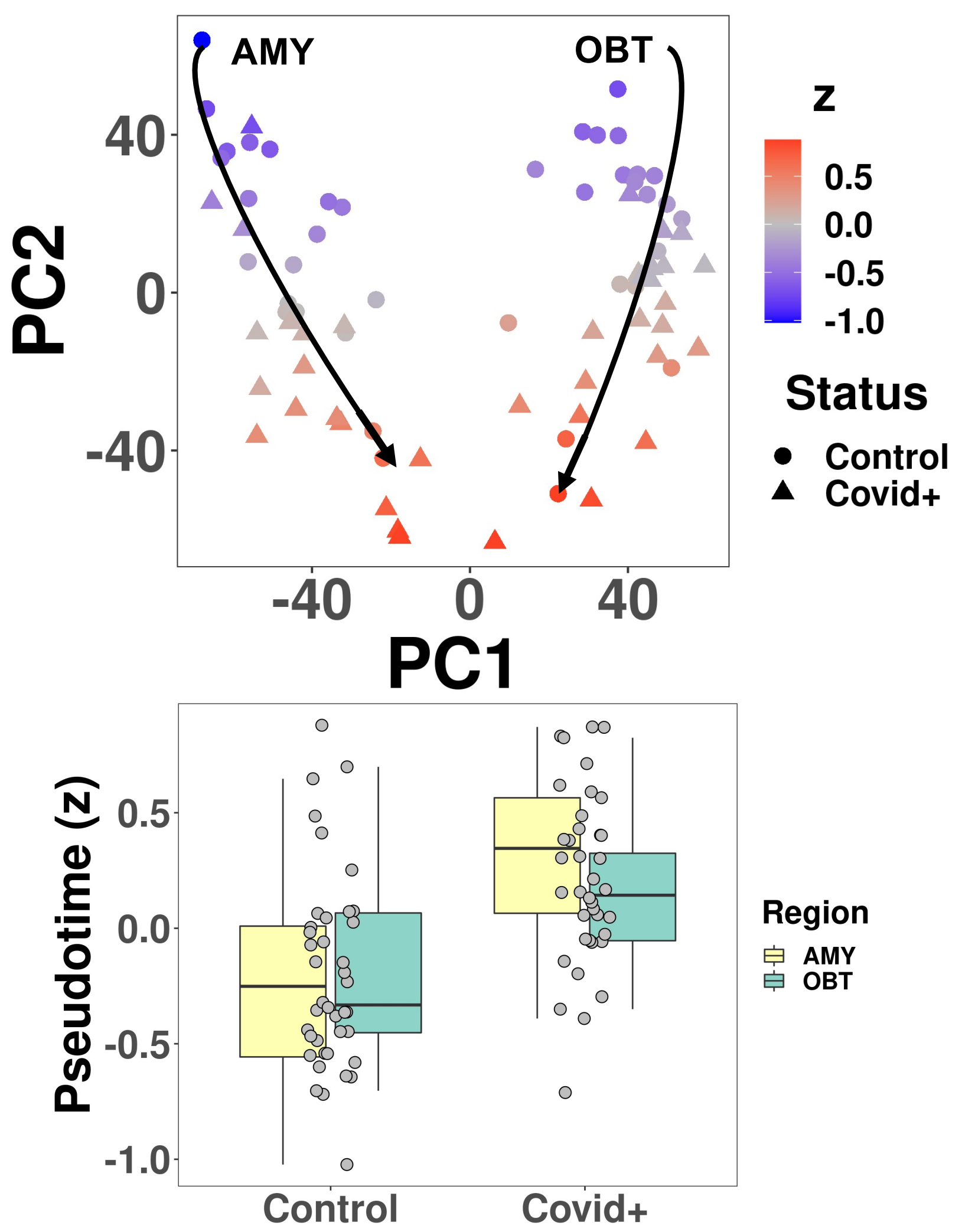

Figure 6. Pseudotime analysis in amygdala and olfactory bulb A)PCA analysis showing converging trajectories for amygdala (left) and olfactory bulb (right).

B)Association between pseudotime and disease status, showing an increase of pseudotime in Covid+ cases. 
medRxiv preprint doi: https://doi.org/10.1101/2021.09.12.21263291; this version posted September 15, 2021. The copyright holder for this preprint (which was not certified by peer review) is the author/funder, who has granted medRxiv a license to display the preprint in perpetuity.

It is made available under a CC-BY-ND 4.0 International license.

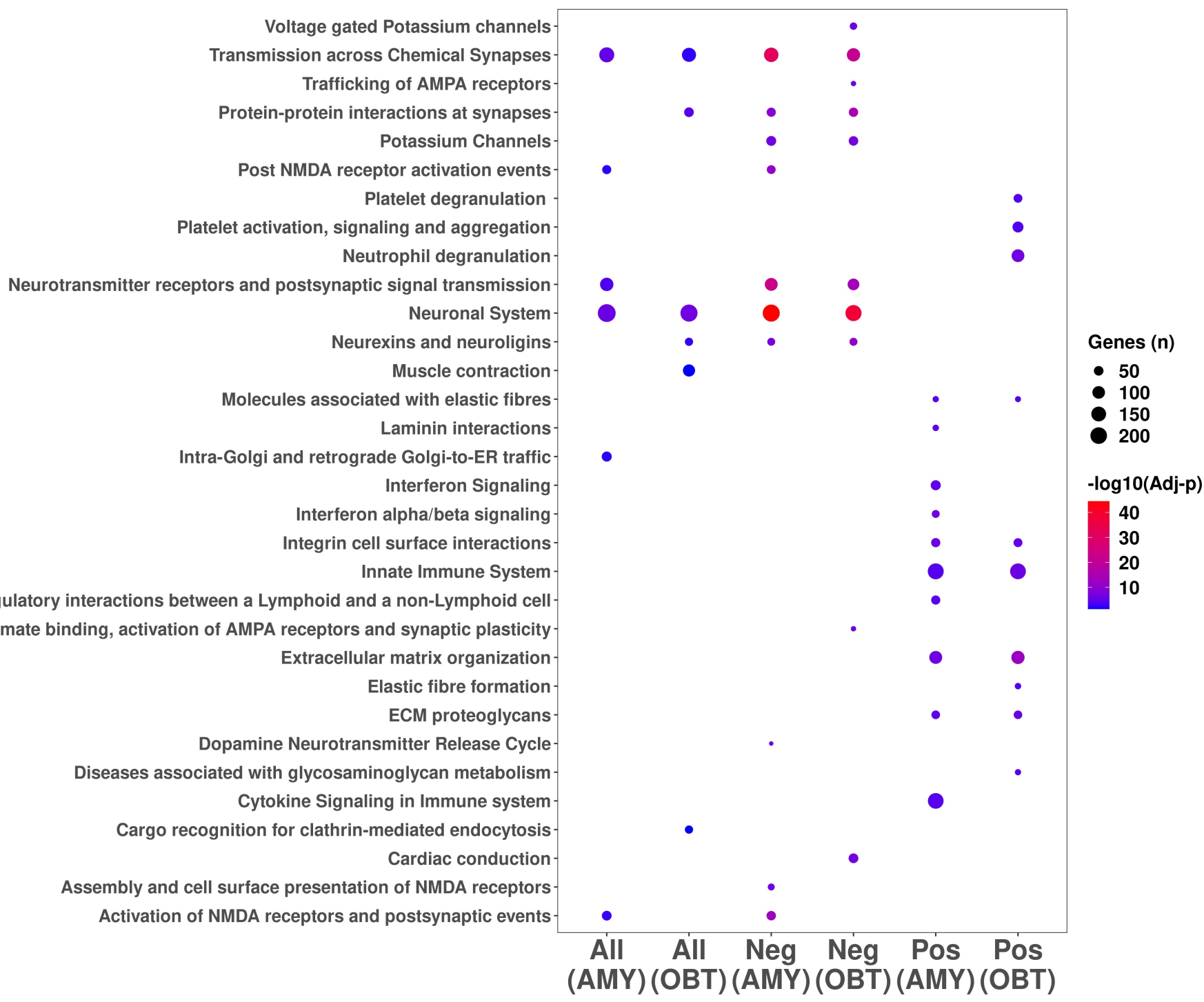

Figure 7. Pathways analysis results (top 10 pathways) conducted using on the genes significantly correlated with pseudotime in amygdala and olfactory bulb. All: all significantly corrected genes

Pos: positive correlation Neg: negative correlation 